\title{
Article \\ Ginsenoside Re Protects against Serotonergic Behaviors Evoked by 2,5-Dimethoxy-4-iodo-amphetamine in Mice via Inhibition of PKC $\delta$-Mediated Mitochondrial Dysfunction
}

\author{
Eun-Joo Shin ${ }^{1,+}$, Ji Hoon Jeong ${ }^{2,+} \mathbb{1}$, Bao-Trong Nguyen ${ }^{1}$, Naveen Sharma ${ }^{1,2}$, Seung-Yeol Nah ${ }^{3}$, \\ Yoon Hee Chung ${ }^{4}$, Yi Lee ${ }^{5}\left(\mathbb{D}\right.$, Jae Kyung Byun ${ }^{6}$, Toshitaka Nabeshima ${ }^{7}$, Sung Kwon Ko ${ }^{8, *}$ \\ and Hyoung-Chun $\mathrm{Kim}^{1, * \mathbb{D}}$
}

1 Neuropsychopharmacology and Toxicology Program, College of Pharmacy, Kangwon National University, Chunchon 24341, Korea; shinej@kangwon.ac.kr (E.-J.S.); nguyenbaotrong.ydct@gmail.com (B.-T.N.); naveenbiochem07@gmail.com (N.S.)

2 Department of Global Innovative Drugs, Graduate School of Chung-Ang University, College of Medicine, Chung-Ang University, Seoul 06974, Korea; jhjeong3@cau.ac.kr

3 Ginsentology Research Laboratory, Department of Physiology, College of Veterinary Medicine and Bio/Molecular Informatics Center, Konkuk University, Seoul 05029, Korea; synah@konkuk.ac.kr

check for updates

Citation: Shin, E.-J.; Jeong, J.H.;

Nguyen, B.-T.; Sharma, N.; Nah, S.-Y.; Chung, Y.H.; Lee, Y.; Byun, J.K.;

Nabeshima, T.; Ko, S.K.; et al. Ginsenoside Re Protects against Serotonergic Behaviors Evoked by 2,5-Dimethoxy-4-iodo-amphetamine in Mice via Inhibition of PKC 8 -Mediated Mitochondrial Dysfunction. Int. J. Mol. Sci. 2021, 22, 7219. https://doi.org/10.3390/ ijms22137219

Academic Editors: Kohji Fukunaga and Ichiro Kawahata

Received: 13 May 2021

Accepted: 29 June 2021

Published: 5 July 2021

Publisher's Note: MDPI stays neutral with regard to jurisdictional claims in published maps and institutional affiliations.

Copyright: (C) 2021 by the authors Licensee MDPI, Basel, Switzerland. This article is an open access article distributed under the terms and conditions of the Creative Commons Attribution (CC BY) license (https:/ / creativecommons.org/licenses/by/ $4.0 /)$.
4 Department of Anatomy, College of Medicine, Chung-Ang University, Seoul 06974, Korea; yoonhee@cau.ac.kr

5 Department of Industrial Plant Science \& Technology, Chungbuk National University, Chungju 28644, Korea; leeyi22@hanmail.net

6 Korea Society of Forest Environmental Research, Namyanju 12106, Korea; forbjk@hanmail.net

7 Advanced Diagnostic System Research Laboratory, Fujita Health University Graduate School of Health Science, Toyoake 470-1192, Japan; tnabeshi@ccmfs.meijo-u.ac.jp

8 Department of Oriental Medical Food and Nutrition, Semyung University, Jecheon 27136, Korea

* Correspondence: skko@semyung.ac.kr (S.K.K.); kimhc@kangwon.ac.kr (H.-C.K.); Tel.: +82-33-250-6917 (H.-C.K.); Fax: +82-33-259-5631 (H.-C.K.)

+ First two authors equally contributed to this work.

\begin{abstract}
It has been recognized that serotonin 2A receptor (5- $\mathrm{HT}_{2 \mathrm{~A}}$ ) agonist 2,5-dimethoxy-4-iodoamphetamine (DOI) impairs serotonergic homeostasis. However, the mechanism of DOI-induced serotonergic behaviors remains to be explored. Moreover, little is known about therapeutic interventions against serotonin syndrome, although evidence suggests that ginseng might possess modulating effects on the serotonin system. As ginsenoside $\operatorname{Re}(\mathrm{GRe})$ is well-known as a novel antioxidant in the nervous system, we investigated whether GRe modulates $5-\mathrm{HT}_{2 \mathrm{~A}}$ receptor agonist DOI-induced serotonin impairments. We proposed that protein kinase $\mathrm{C} \delta(\mathrm{PKC} \delta)$ mediates serotonergic impairments. Treatment with GRe or 5-HT $2 \mathrm{~A}$ receptor antagonist MDL11939 significantly attenuated DOI-induced serotonergic behaviors (i.e., overall serotonergic syndrome behaviors, head twitch response, hyperthermia) by inhibiting mitochondrial translocation of $\mathrm{PKC} \delta$, reducing mitochondrial glutathione peroxidase activity, mitochondrial dysfunction, and mitochondrial oxidative stress in wild-type mice. These attenuations were in line with those observed upon PKC $\delta$ inhibition (i.e., pharmacologic inhibitor rottlerin or PKC $\delta$ knockout mice). Furthermore, GRe was not further implicated in attenuation mediated by PKC $\delta$ knockout in mice. Our results suggest that PKC $\delta$ is a therapeutic target for GRe against serotonergic behaviors induced by DOI.
\end{abstract}

Keywords: ginsenoside $\mathrm{Re}$; $5-\mathrm{HT}_{2 \mathrm{~A}}$ receptor agonist DOI; serotonergic behaviors; head twitch response; hyperthermia; mitochondrial burden; hypothalamus; PKC $\delta$ knockout mice

\section{Introduction}

Ginseng (Panax ginseng) is a naturally occurring herb. Commercially available ginseng formulations are mainly extracted from the roots of ginseng plants [1]. Ginsenosides, a form of triterpene glycosides (saponins), are the major bioactive ingredients in ginseng. Importantly, it has been demonstrated that ginsenosides enhance brain function 
via antioxidative and antineuroinflammatory activities. In addition, they slow down or attenuate numerous neurodegenerative and psychiatric disorders. There are approximately 150 ginsenosides, and among them, 40 have been found in Panax ginseng per se [2,3]. In particular, ginsenoside $\operatorname{Re}(\mathrm{GRe})$ is the main ginsenoside that has shown potential neuroprotective activities [4]. Although mostly the root of the ginseng plant has been used in herbal medicine, earlier studies have reported that the main bioactive component of ginseng (i.e., GRe) is more abundantly present in berries, flower buds, and leaves than in the roots [4-8], indicating the important pharmacoeconomical intervention of GRe for developing naturally occurring drug resources. Therefore, in our previous studies, we have investigated the neuropsychoprotective activities of GRe [9-13].

Serotonin syndrome is a severe hazardous condition that can be life-threatening [14], and the syndrome includes altered mental status, autonomic responses, and the triad of motor symptoms $[15,16]$. Excessive serotonin release and consequent overactivation of central and peripheral serotonin receptors are known to cause serotonin syndrome [14]. For instance, abuse of serotonergic compounds, such as methylenedioxymethamphetamine (MDMA) [17-22], 5-methoxy-N,N-dimethyltryptamine (5-MeO-DMT) [23], and psilocybin [24], or dissociative drugs, such as dextromethorphan [25-28], has been reported to provoke serotonin syndrome in humans. Indeed, it has been reported that frequent usage of antidepressants, such as monoamine oxidase (MAO) inhibitors and selective serotonin reuptake inhibitors (SSRIs), enhances the risk of serotonin syndrome [14,29]. Therefore, the fact that sustained exposure to antidepressant drugs presents a potential for inducing serotonin syndrome is of concern.

For example, fluoxetine, an SSRI, has various effects on energy metabolism in the hepatocellular mitochondria of rats, and it is potentially toxic at high doses [30]. It affects apoptosis by increasing the voltage sensitivity of the mitochondrial voltage-dependent anion channel [31]. Fluoxetine induces the inhibition of oxidative phosphorylation and decreases mitochondrial ATP synthase activity in the rat brain [32]. Exposure to norfluoxetine, an active metabolite of fluoxetine, reduces the membrane potential and activity of mitochondrial complexes and leads to apoptotic changes [33]. However, it is unclear whether mitochondrial dysfunction is involved in serotonin syndrome behaviors.

Among serotonin receptors, post-synaptic $5-\mathrm{HT}_{1 \mathrm{~A}}$ and $5-\mathrm{HT}_{2 \mathrm{~A}}$ receptors have been suggested to be importantly involved in serotonin syndrome [14,34]. Consistently, it has been reported that the specific $5-\mathrm{HT}_{1 \mathrm{~A}}$ receptor agonist $8-\mathrm{OH}-\mathrm{DPAT}$ or the specific $5-\mathrm{HT}_{2 \mathrm{~A}}$ receptor agonist (4-Bromo-3,6-dimethoxybenzocyclobuten-1-yl)methylamine hydrobromide TCB-2 induces serotonin syndrome behavior in mice [35-37]. In most cells and tissues, 5-HT receptors activate phospholipase $\mathrm{C}$, which causes stimulation of protein kinase C (PKC) [38]. Among PKC isozymes, PKC $\delta$ is mainly involved in several cellular transduction pathways coupled with oxidative stress, inflammation, and cell death [39-45]. We [13,41-49] and others [50-53] have suggested that PKC is important for neuropsychotoxicity induced by amphetamine and its analogues. In particular, the PKC $\delta$ gene is a crucial target for generating serotonergic behaviors $[35,54]$.

We have recently filed a patent (patent number KR 1-1-2020-1158807-40: The pharmaceutical composition for the prevention and treatment of serotonin syndrome behaviors). In this study, we observed that protopananxatriol saponins (PPT) blocked serotonergic behaviors in mice and that the GRe in PPT played a major role in attenuating against serotonin syndrome behaviors. Thus, in the present study, we attempted to extend our knowledge of the GRe-mediated pharmacological mechanism against the serotonergic behaviors induced by 2,5-dimethoxy-4-iodo-amphetamine (DOI), an amphetamine analog and a 5- $\mathrm{HT}_{2 \mathrm{~A}}$ receptor agonist. We investigated the following: (1) whether DOI-mediated $5-\mathrm{HT}_{2 \mathrm{~A}}$ receptor stimulation induces mitochondrial dysfunction and the consequent oxidative burden; (2) whether PKC $\delta$ activation is involved in DOI-induced serotonergic changes, mitochondrial burden, and serotonergic behaviors using pharmacological and genetic inhibition of PKC $\delta$; (3) whether GRe affects DOI-induced neuronal and behavioral changes; and (4) whether GRe modulates its effects by affecting PKC $\delta$ activation and consequent 
changes after DOI treatment. Since our recent studies have showed that the serotonergic impairment in the hypothalamus is much more pronounced than in the hippocampus or in the prefrontal cortex in several serotonin syndrome models [38-40], we have focused on the hypothalamic changes in the present study. We observed that GRe attenuated DOI-induced serotonin syndrome behaviors by inhibiting mitochondrial translocation of $\mathrm{PKC} \delta$, mitochondrial dysfunction, and mitochondrial oxidative damage, and impaired enzymatic antioxidant systems in the hypothalami of mice. Consistently, PKC $\delta$ knockout (PKC $\delta \mathrm{KO}$ ) attenuated against these neurobehavioral impairments caused by DOI in mice.

\section{Results}

2.1. Effect of GRe, Rottlerin, or MDL11939 (MDL) on the Mitochondrial Translocation of PKC $\delta$ Induced by DOI in the Wild-Type Mice

We recently demonstrated that hypothalamic PKC $\delta$ levels might play a critical role in inducing serotonin behaviors $[35,54,55]$. As shown in Figure 1 of the experimental design, we investigated whether GRe, the PKC $\delta$ inhibitor rottlerin, or the $5-\mathrm{HT}_{2 \mathrm{~A}}$ receptor antagonist MDL affects the mitochondrial translocation of PKC $\delta$ induced by the $5-\mathrm{HT}_{2 \mathrm{~A}}$ agonist DOI. As shown in Figure 2, DOI treatment significantly increased cytosolic PKC $\delta$ $(p<0.05$ vs. saline/saline; Figure $2 \mathrm{~A})$ and mitochondrial PKC $\delta$ ( $p<0.01$ vs. saline/saline; Figure 2B) in wild-type mice. The effect of DOI seemed more evident in the mitochondrial fraction than the cytosolic fraction. This increase was significantly inhibited $(p<0.01 \mathrm{vs}$. saline/DOI) by GRe, rottlerin, or MDL, and the inhibition by GRe or MDL paralleled that by rottlerin (Figure 2B).

A.

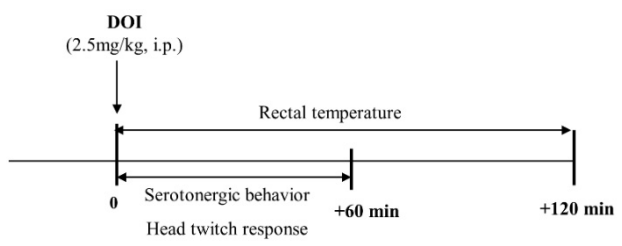

B.
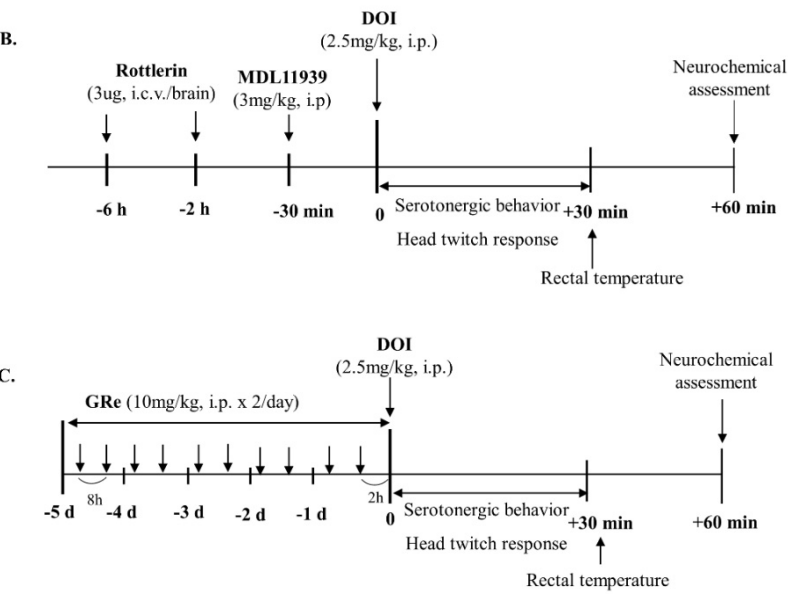

Figure 1. Schematic representation of experimental protocol for investigating the effect of GRe on the serotonergic behaviors induced by DOI in wild-type and PKC $\delta$ KO mice. DOI-induced serotonin syndrome behaviors and head twitch responses were analyzed every 6 min for the first $1 \mathrm{~h}$, and rectal temperature was estimated every $15 \mathrm{~min}$ for $2 \mathrm{~h}$ (the first $1 \mathrm{~h}$ plus the second $1 \mathrm{~h}$ ) (A). Rottlerin was given ( $3 \mu$ g, i.c.v. /brain) $6 \mathrm{~h}$ and $2 \mathrm{~h}$ before the DOI administration. MDL11939 (3 mg/kg, i.p.) was given $30 \mathrm{~min}$ prior to DOI injection (B). GRe $(10 \mathrm{mg} / \mathrm{kg}$, i.p.) was injected twice a day at an $8 \mathrm{~h}$ interval for 5 consecutive days. DOI was injected $2 \mathrm{~h}$ after the final administration of GRe (C). Mice were sacrificed $1 \mathrm{~h}$ post-DOI-administration for assessing neurochemical changes (B,C). GRe, ginsenoside Re; DOI, 2,5-dimethoxy-4-iodo-amphetamine. 


\section{A. Cytosol fraction}

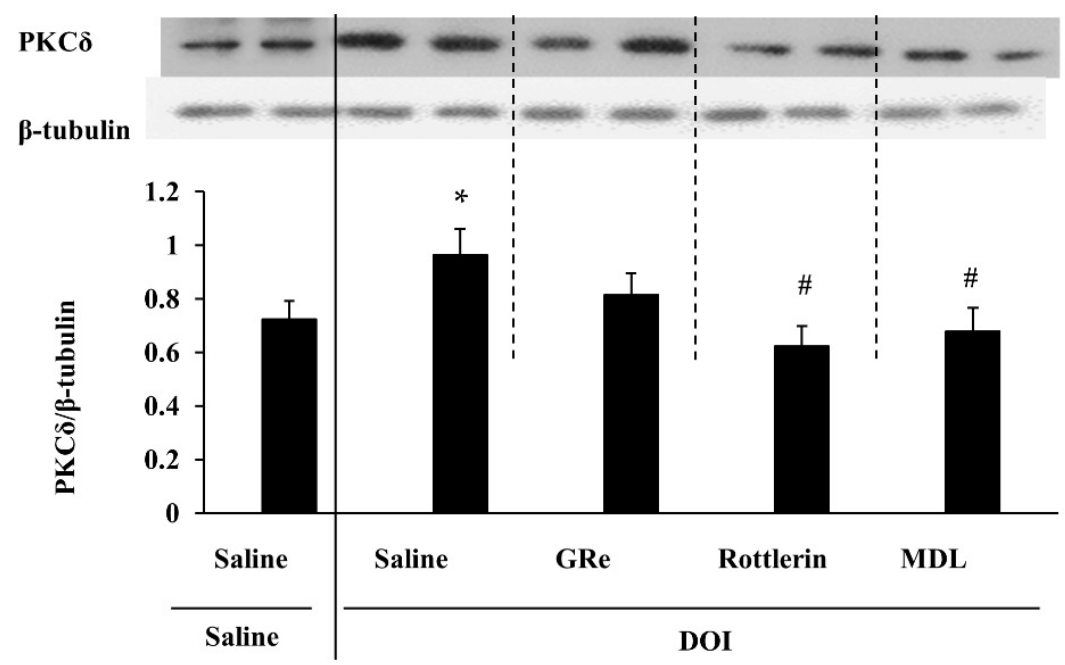

B. Mitochondrial fraction

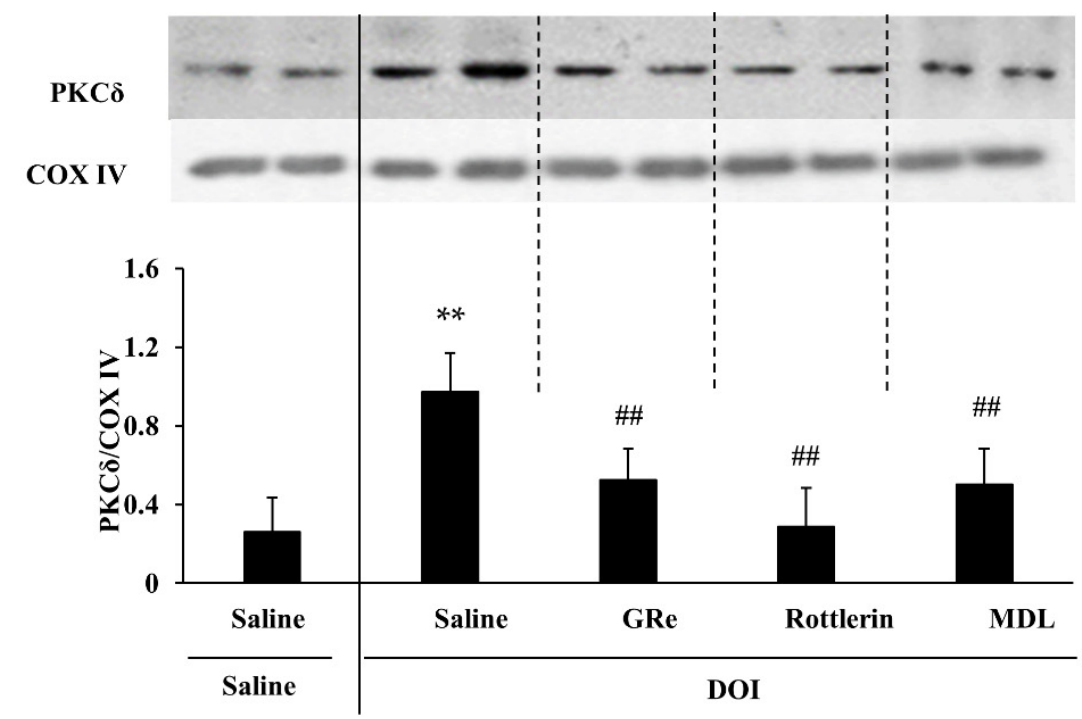

Figure 2. Effect of GRe, rottlerin, or MDL on the cytosolic (A) and mitochondrial (B) expression of PKC 60 min after the DOI administration in the hypothalamus of wild-type mice. Data are expressed as the mean \pm SEM (4-6 animals). DOI, 2,5-dimethoxy-4-iodo-amphetamine; MDL, MDL11939; GRe, ginsenoside Re. ${ }^{*} p<0.05,{ }^{* *} p<0.01$ vs. saline/saline. ${ }^{\#} p<0.05,{ }^{\# \#} p<0.01$ vs. saline/DOI (one-way ANOVA was performed for statistical analysis followed by Fisher's LSD pairwise comparisons). For more details refer to Supplementary Figure S1. 


\subsection{Effect of GRe or MDL11939 (MDL) on the Alterations in Mitochondrial Membrane Potential and Intra-Mitochondrial $\mathrm{Ca}^{2+}$ Level Elicited by DOI in the Wild-Type and PKC $\delta$ KO Mice}

Earlier reports have indicated that DOI facilitated mitochondrial dysfunction [56]. We $[10,12,13,57]$ and other researchers [58-60] have demonstrated that GRe attenuates mitochondrial dysfunction induced by neurotoxic insults. In addition, we have also reported that GRe attenuates mitochondrial dysfunction induced by dopaminergic insult via genetic and pharmacological inhibition of PKC $\delta[12,13]$. Consistently, we observed here that DOI remarkably augmented the mitochondrial translocation of PKC $\delta$ (Figure 2B). Thus, we investigated whether GRe or PKC $\delta$ inhibition modulates the mitochondrial membrane potential and intramitochondrial $\mathrm{Ca}^{2+}$ levels induced by DOI. In addition, we examined the effect of 5- $\mathrm{HT}_{2 \mathrm{~A}}$ antagonism in our experimental conditions.

As shown in Figure 3A, DOI caused a significant decrease ( $p<0.05$ vs. saline/saline) in the mitochondrial membrane potential in the wild-type mice, whereas genetic depletion of PKC $\delta$ significantly attenuated ( $p<0.05$ vs. saline/DOI/wild-type) the decrease caused by DOI. Treatment with GRe, rottlerin, or MDL significantly inhibited $(p<0.05$ vs. saline/DOI) DOI-induced decrease in the mitochondrial membrane potential in wildtype mice. However, neither GRe nor MDL affected PKC $\delta \mathrm{KO}$-mediated attenuation (Figure 3A).

\section{A. Mitochondrial membrane potential}

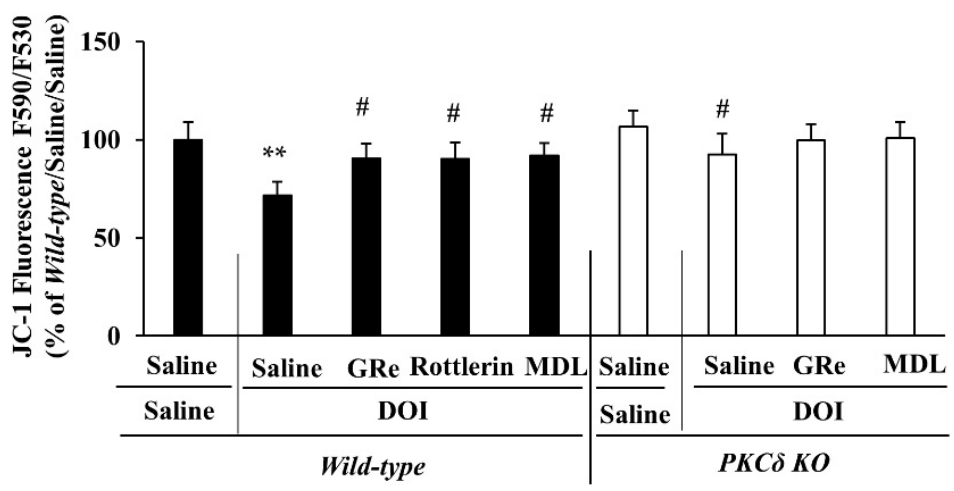

B. Intra-mitochondrial $\mathrm{Ca}^{2+}$

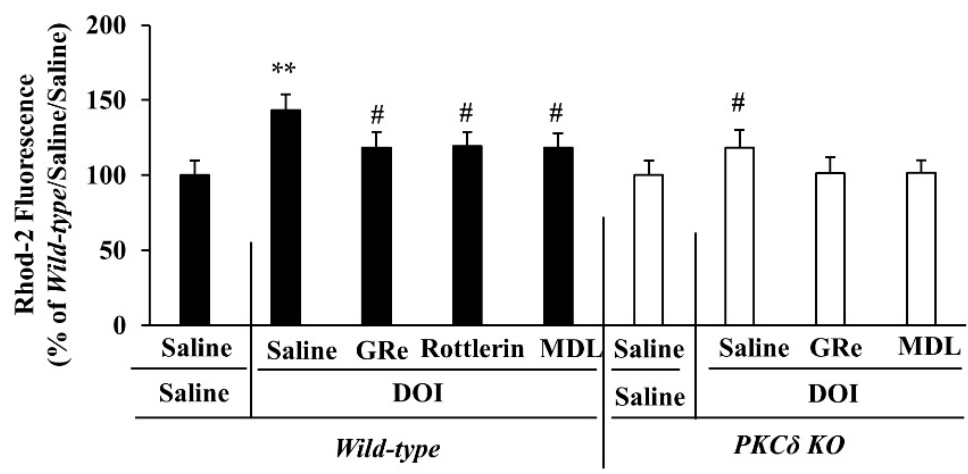

Figure 3. Effect of GRe or MDL on the alterations in mitochondrial membrane potential (A) and intra-mitochondrial $\mathrm{Ca}^{2+}$ level (B) induced by DOI in the hypothalamus of wild-type and PKC $\delta$ KO mice. Data are expressed as the mean \pm SEM (6 animals/group). DOI, 2,5-dimethoxy-4-iodoamphetamine; MDL, MDL11939; GRe, ginsenoside Re; PKC $\delta$ KO, PKC $\delta$ knockout mice. ** $p<0.01$ vs. saline/saline/wild-type. ${ }^{*} p<0.05$ vs. saline/DOI/wild-type (one-way ANOVA was performed for statistical analysis followed by Fisher's LSD pairwise comparisons). 
As shown in Figure 3B, DOI significantly increased ( $p<0.05$ vs. saline/saline) intramitochondrial $\mathrm{Ca}^{2+}$ accumulation, this increase was significantly alleviated $(p<0.05 \mathrm{vs}$. saline/DOI) by GRe, rottlerin, or MDL in the wild-type mice. PKC $\delta$ KO also significantly attenuated ( $p<0.05$ vs. saline/DOI/wild-type) the DOI-induced increase in intramitochondrial $\mathrm{Ca}^{2+}$ levels in mice. However, neither GRe nor MDL significantly altered the PKC $\delta$ KO-mediated attenuation (Figure 3B).

\subsection{Effect of GRe or MDL11939 (MDL) on the Alterations in the Mitochondrial Complex I and Complex II Activities Caused by DOI in Wild-Type and PKC $\delta$ KO Mice}

DOI treatment significantly decreased complex I ( $p<0.01$ vs. saline/saline; Figure $4 \mathrm{~A}$ ) and complex II ( $p<0.05$ vs. saline/saline; Figure 4 B) activities in the wild-type mice. These effects were significantly attenuated ( $p<0.05$ vs. saline/DOI/wild-type) by PKC $\delta$ KO in mice. Treatment with GRe, PKC $\delta$ inhibitor rottlerin, or MDL resulted in a significant attenuation ( $p<0.05$ vs. saline/DOI) of the DOI-induced decrease in complex I activity in the wild-type mice. GRe, rottlerin, or MDL appeared to attenuate this effect without reaching statistical significance. In addition, GRe or MDL did not significantly alter PKC $\delta$ KO-mediated potentials against mitochondrial complex I and II activities caused by DOI (Figure 4).

A.

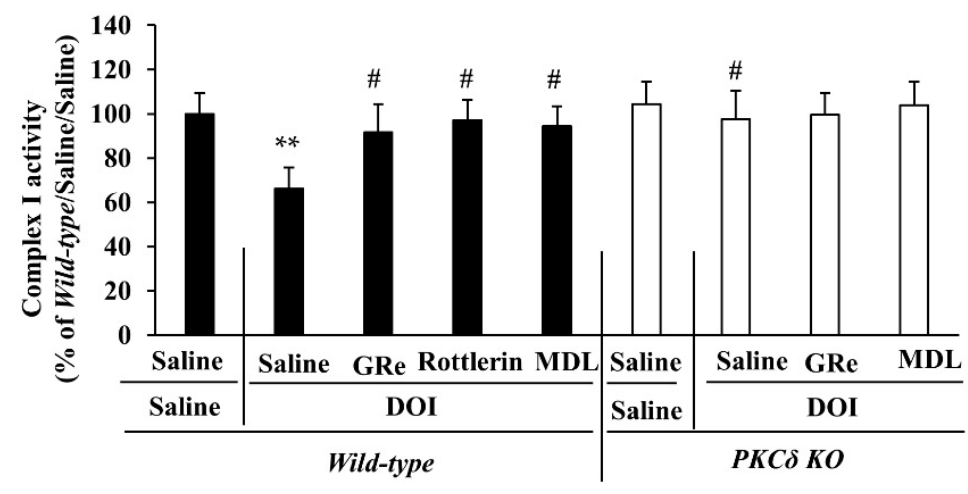

B.

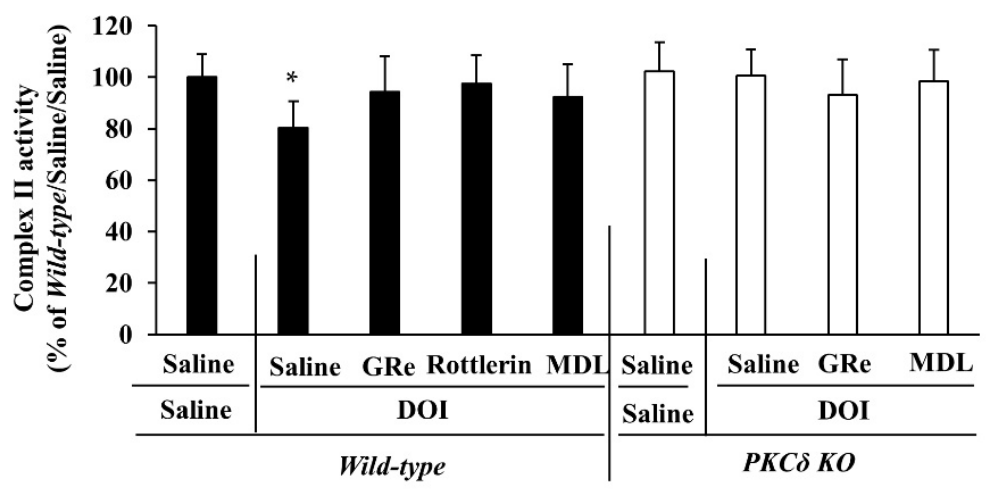

Figure 4. Effect of GRe or MDL on the changes in mitochondrial complex I (A) and complex II (B) activities caused by DOI in the hypothalamus of wild-type and PKC $\delta$ KO mice. Data are expressed as the mean \pm SEM (6 animals/group). DOI, 2,5-dimethoxy-4-iodo-amphetamine; MDL, MDL11939; GRe, ginsenoside Re; PKC $\delta$ KO, PKC $\delta$ knockout mice. ${ }^{*} p<0.05,{ }^{* *} p<0.01$ vs. saline/saline/wildtype. ${ }^{\#} p<0.05$ vs. saline/DOI/wild-type (one-way ANOVA was performed for statistical analysis followed by Fisher's LSD pairwise comparisons). 
2.4. Effect of GRe or MDL11939 (MDL) on DOI-Induced Oxidative Stress in the Mitochondrial and Cytosolic Fractions of the Hypothalamus of Wild-Type and PKC $\delta$ KO Mice

We have recently demonstrated that 5-HT receptors require PKC $\delta$ to induce serotonergic behaviors and that PKC $\delta$ is an important factor for the harmful oxidant generation $[35,54]$. However, it remains to be elucidated whether the mitochondrial oxidative burden is involved in serotonergic behaviors. In this study, we found that DOI-induced oxidative stress appeared to be more evident in the mitochondrial fraction than in the cytosolic fraction, suggesting that mitochondria are more susceptible to DOI insult than cytosol. As shown in Figure 5, oxidative parameters (reactive oxygen species (ROS) formation, 4-hydroxynonenal (HNE), and protein carbonyl) in the mitochondrial and cytosolic fractions were significantly increased (cytosolic level of ROS, HNE, or protein carbonyl: $p<0.05$ vs. saline/saline; mitochondrial level of ROS, HNE, or protein carbonyl: $p<0.01$ vs. saline/saline) $1 \mathrm{~h}$ post-DOI treatment in wild-type mice.

A. Cytosol fraction ROS formation

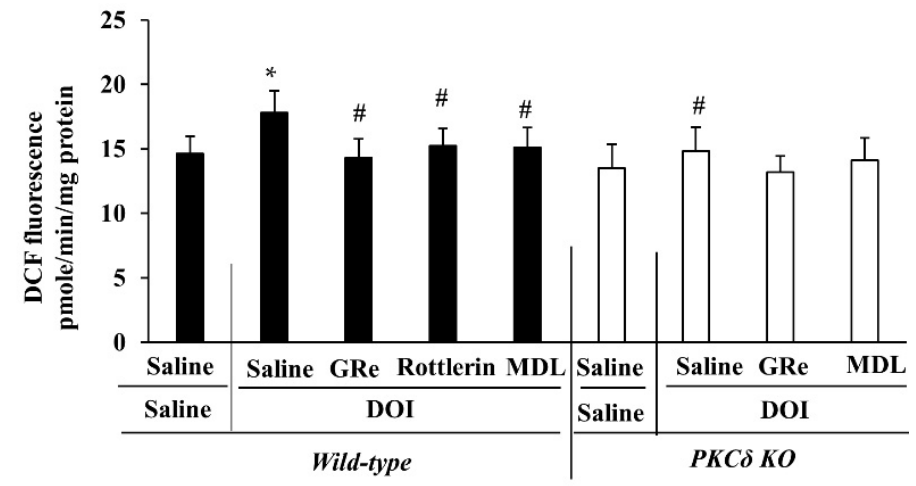

B. Mitochondrial fraction

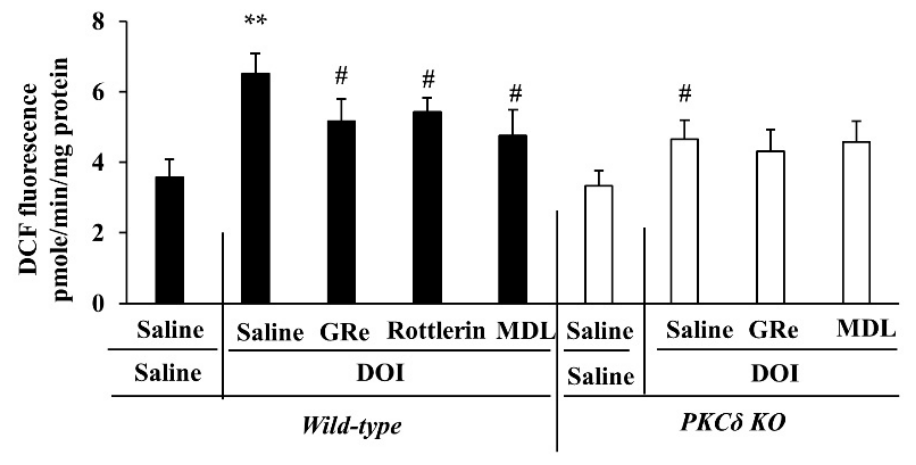

Figure 5. Cont. 
C. Cytosol fraction 4-HNE

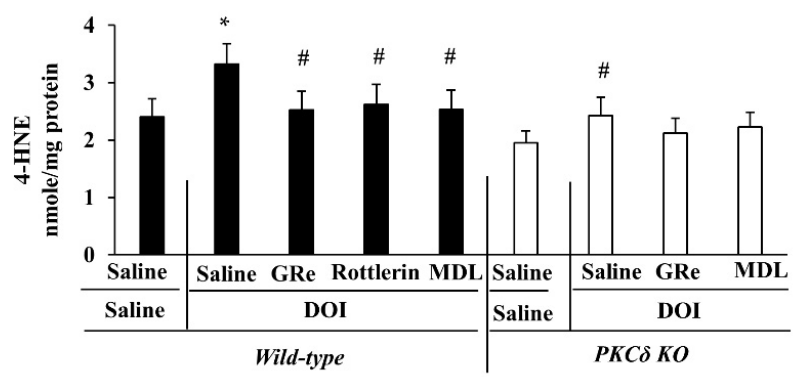

D. Mitochondrial fraction
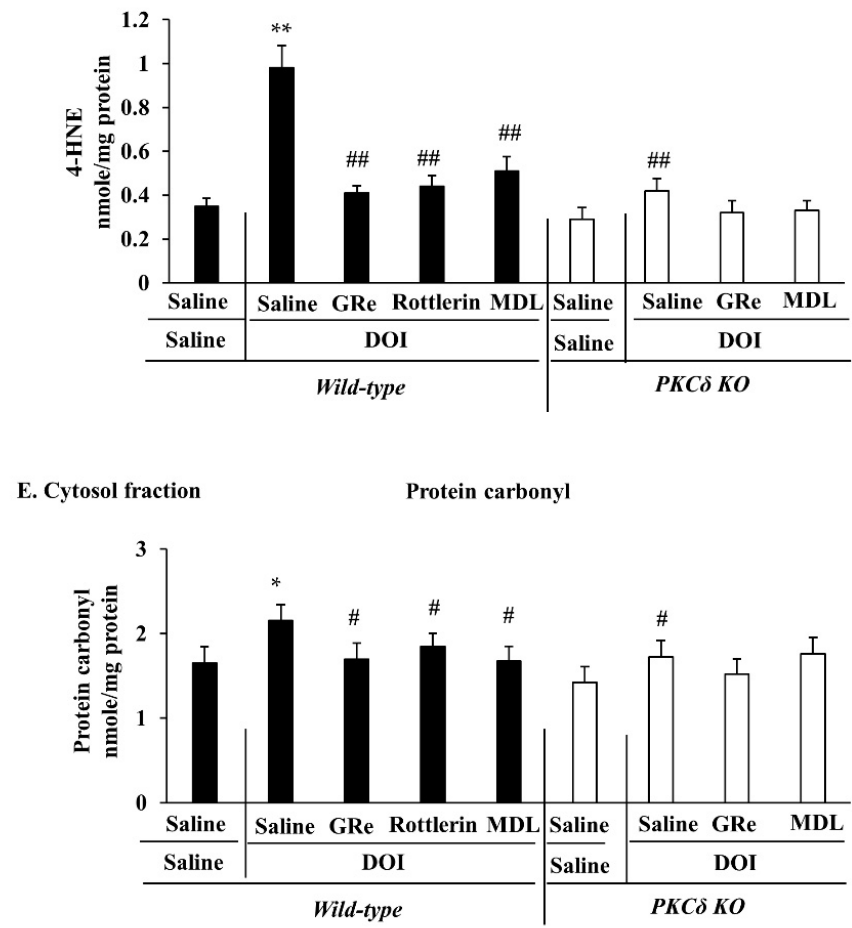

F. Mitochondrial fraction

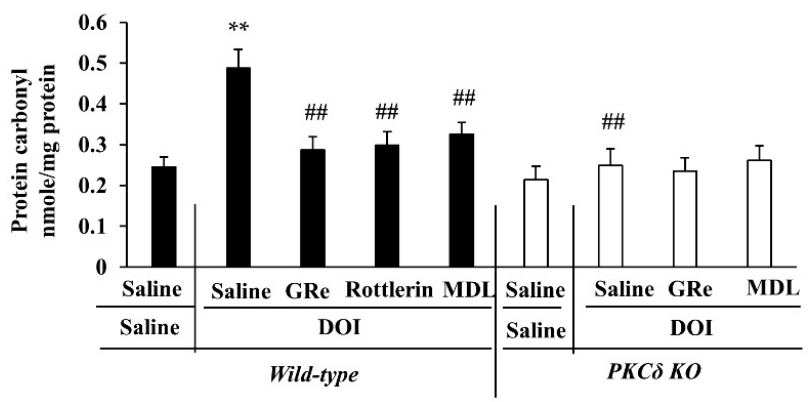

Figure 5. Effect of GRe or MDL on the DOI-induced oxidative stress in the cytosolic $(\mathbf{A}, \mathbf{C}, \mathbf{E})$ and mitochondrial $(\mathbf{B}, \mathbf{D}, \mathbf{F})$ fractions in the hypothalamus of wild-type and PKC $\delta$ KO mice. DOI-induced oxidative stress was assessed by ROS (A,B), 4-HNE (C,D), and protein carbonyl (E,F) levels. DOI, 2,5-dimethoxy-4-iodo-amphetamine; MDL, MDL11939; GRe, ginsenoside Re; PKC $\delta$ KO, PKC $\delta$ knockout mice. Data are expressed as the mean \pm SEM (6 animals $/$ group). ${ }^{*} p<0.05$, ${ }^{* *} p<0.01$ vs. saline/saline/wild-type. ${ }^{\#} p<0.05,{ }^{\# \#} p<0.01$ vs. saline/DOI/wild-type (one-way ANOVA was performed for statistical analysis followed by Fisher's LSD pairwise comparisons). 
DOI-induced increases in oxidative parameters were significantly attenuated by PKC $\delta$ $\mathrm{KO}$ in mice (cytosolic ROS, HNE, or protein carbonyl: $p<0.05$ vs. saline/DOI wild-type; mitochondrial ROS, HNE, or protein carbonyl: $p<0.01$ vs. saline/DOI/wild-type). GRe, rottlerin, or MDL significantly inhibited DOI-induced oxidative damage (cytosolic ROS, HNE, or protein carbonyl: $p<0.05$ vs. saline/DOI; mitochondrial ROS, HNE, or protein carbonyl: $p<0.01$ vs. saline/DOI) in either fraction of wild-type mice. However, in the presence of DOI, GRe or MDL did not significantly affect antioxidant activity afforded by $\mathrm{PKC} \delta \mathrm{KO}$ in mice (Figure 5).

2.5. Effect of GRe or MDL11939 (MDL) on Changes in the Mitochondrial and Cytosolic Activities of Superoxide Dismutase (SOD) and Glutathione Peroxidase (GPX) Induced by DOI in Wild-Type and PKC $\delta$ KO Mice

It has been well-recognized that enzymatic antioxidants such as SODs, catalase, and peroxidases (i.e., GPx) are oxyradical scavengers; SOD catalyzes the dismutation of $\mathrm{O}_{2}$ (superoxide anion) to produce hydrogen peroxide $\left(\mathrm{H}_{2} \mathrm{O}_{2}\right)$, and then catalase or GPx might catalyze the reduction of $\mathrm{H}_{2} \mathrm{O}_{2}$ to water. However, it is also apparent that in most eukaryotic cells, catalase is restricted to isolated compartments such as peroxisomes [61-63]; in particular, SOD and peroxidases (mainly GPx) are located in the cytoplasm and mitochondria of the cells [63-66]. Here, we asked whether GRe or genetic/pharmacological inhibition of PKC $\delta$ or MDL modulates SOD and GPx activities induced by DOI.

As shown in Figure 6, DOI significantly increased cytosolic SOD (SOD-1) $(p<0.05$ vs. saline/saline) and mitochondrial SOD (SOD-2) activities ( $p<0.01 \mathrm{vs}$. saline/saline) $60 \mathrm{~min}$ post-treatment in wild-type mice (Figure $6 \mathrm{~A}, \mathrm{~B}$ ). At that time, cytosolic and mitochondrial GPx activities were significantly decreased (cytosolic and mitochondrial fractions, $p<0.05$ and $p<0.01$ vs. saline/saline, respectively) in the presence of DOI in wild-type mice (Figure 6C,D).

GRe, rottlerin, or MDL significantly inhibited DOI-induced increases in cytosolic SOD1 (DOI plus GRe, rottlerin, or MDL: $p<0.05$ vs. saline/DOI) and mitochondrial SOD-2 (DOI plus GRe, rottlerin, or MDL: $p<0.01$ vs. saline/DOI) activities (Figure 6A,B). Consistently, either one significantly attenuated decreases in cytosolic (DOI plus GRe, rottlerin, or MDL: $p<0.05$ vs. saline/DOI) and mitochondrial (DOI plus GRe, rottlerin, or MDL: $p<0.01$ vs. saline/DOI) GPx activities from DOI insult in wild-type mice (Figure 6C,D). We observed that mitochondrial enzymatic antioxidants appeared to be more susceptible to DOI burden than cytosolic enzymatic antioxidants. Efficacy of GRe, rottlerin, or MDL appeared to be selective in the mitochondrial fraction (>cytosolic fraction).

PKC $\delta$ KO also significantly attenuated DOI-induced changes in SOD-1 $(p<0.05$ vs. saline/DOI/wild-type), SOD-2 ( $p<0.01$ vs. saline/DOI/wild-type), cytosolic GPx ( $p<0.05$ vs. saline/DOI/wild-type), and mitochondrial GPx ( $p<0.01$ vs. saline/DOI/wild-type) activities in mice. However, neither GRe nor MDL altered PKC $\delta$ KO-mediated attenuation of DOI-induced deregulation of cytosolic and mitochondrial SOD and GPx activities in mice (Figure 6A-D), suggesting that PKC $\delta$ is a critical target of antioxidant potential exhibited by GRe or MDL.

2.6. Effect of GRe or MDL11939 (MDL) against Serotonergic Behaaviors, Head Twitch Response, and Hyperthermia Caused by DOI in Wild-Type and PKC $\triangle$ KO Mice

Treatment with DOI resulted in significant hyperthermia, complex serotonergic behaviors (i.e., hind limb abduction, forepaw treading, straub tail, low body posture, lateral head weaving, and tremor; Supplementary Figure S2), and head twitch response in wild-type mice. PKC $\delta$ KO significantly attenuated DOI-induced overall serotonergic behavioral scores (12 min and $30 \mathrm{~min}$ post-DOI administration: $p<0.05 \mathrm{vs}$. DOI/wild-type; $18 \mathrm{~min}$ and 24 min post-DOI administration: $p<0.01$ vs. DOI/wild-type) and head twitch response number $(6 \mathrm{~min}, 12 \mathrm{~min}, 18 \mathrm{~min}$, and $42 \mathrm{~min}$ post-DOI administration: $p<0.05$ vs. DOI/wild-type; $24 \mathrm{~min}, 30 \mathrm{~min}$, and $36 \mathrm{~min}$ post-DOI administration: $p<0.01$ vs. DOI/wild-type), and hyperthermia (30 min, $45 \mathrm{~min}, 60 \mathrm{~min}, 75 \mathrm{~min}, 90 \mathrm{~min}$, and $105 \mathrm{~min}$ post-DOI administration: $p<0.05$ vs. DOI/wild-type) (Figure 7A,C,E). 
A. Cytosolic Cu, Zn-SOD (SOD-1)

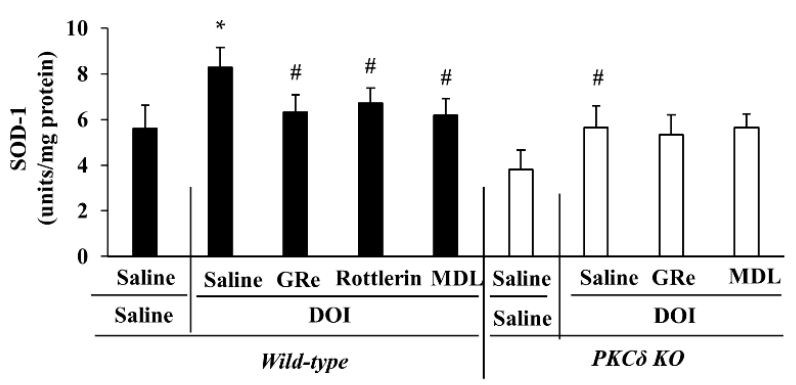

B. Mitochondrial Mn-SOD (SOD-2)

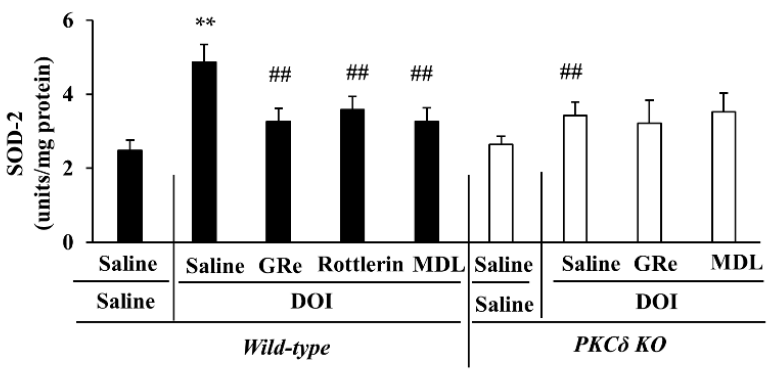

C. Cytosol fraction

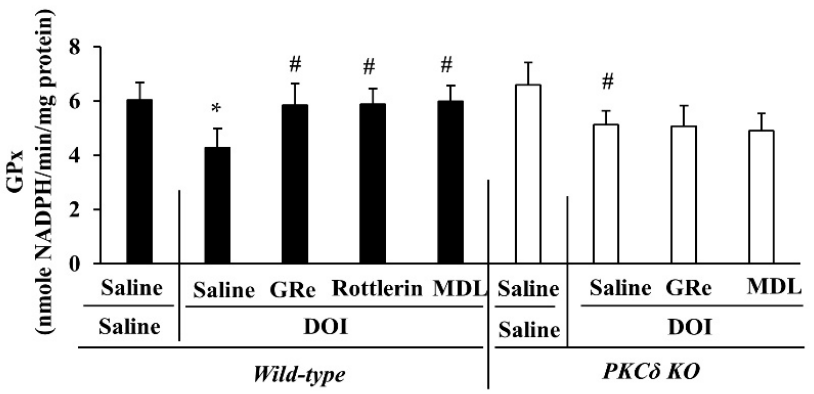

D. Mitochondrial fraction

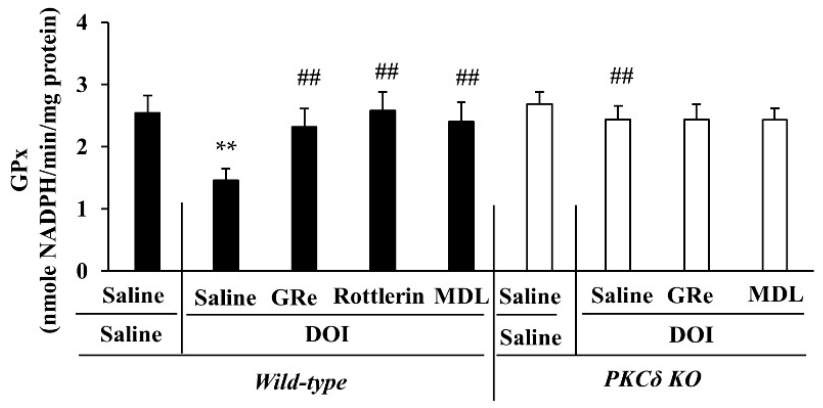

Figure 6. Effect of GRe or MDL on the changes in the activities of cytosolic $\mathrm{Cu}, \mathrm{Zn}-\mathrm{SOD}$ (SOD-1; (A)), mitochondrial Mn-SOD (SOD-2; (B)), cytosolic GPx (C), and mitochondrial GPx (D) induced by DOI in the hypothalamus of wild-type and PKC $\delta \mathrm{KO}$ mice. DOI, 2,5-dimethoxy-4-iodo-amphetamine; MDL, MDL11939; GRe, ginsenoside Re; PKC $\delta$ KO, PKC $\delta$ knockout mice. Data are expressed as the mean \pm SEM ( 6 animals/group). ${ }^{*} p<0.05$, ${ }^{* *} p<0.01$ vs. saline/saline/wild-type. ${ }^{\#} p<$ $0.05,{ }^{\#} p<0.01$ vs. saline/DOI/wild-type (one-way ANOVA was performed for statistical analysis followed by Fisher's LSD pairwise comparisons). 
A. Overall serotonergic behavioral score

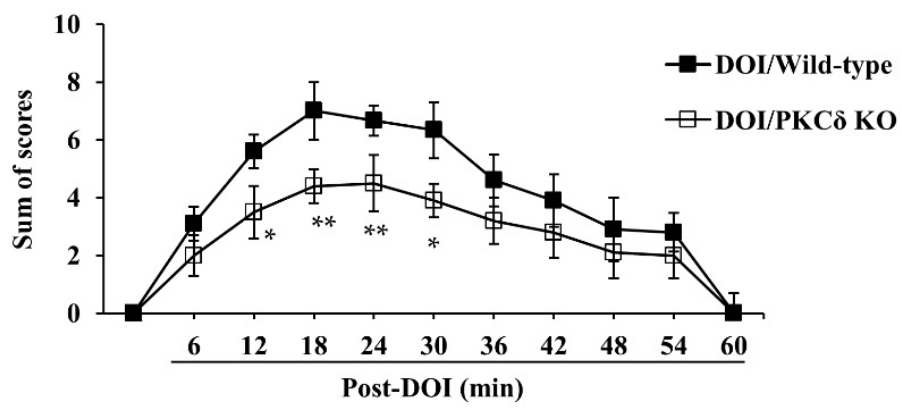

B. Overall serotonergic behavioral score (the first 30 min post DOI)

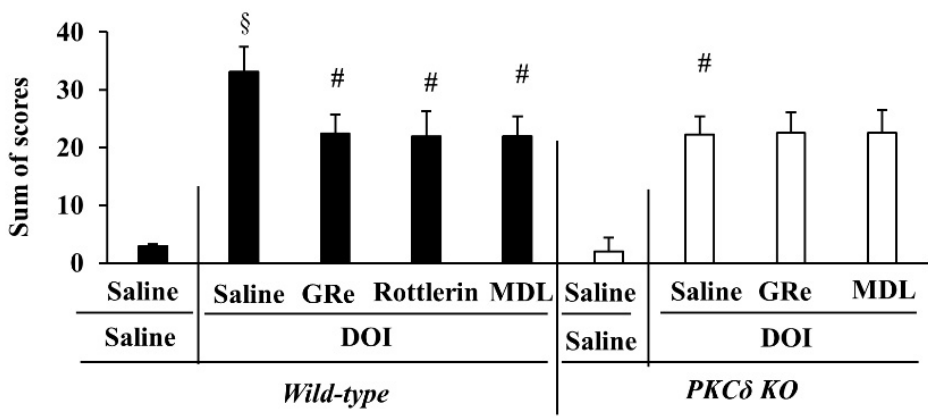

C.

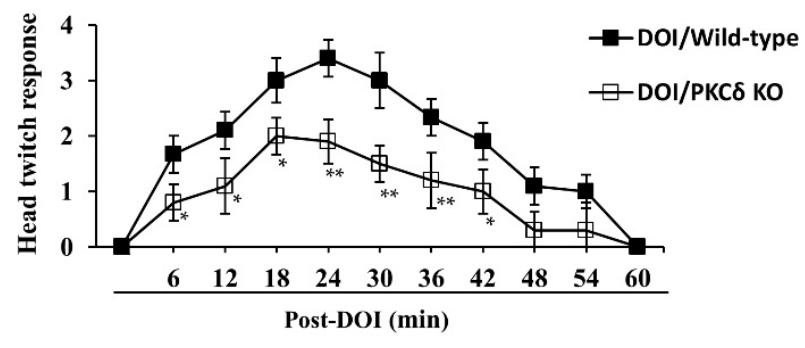

D.

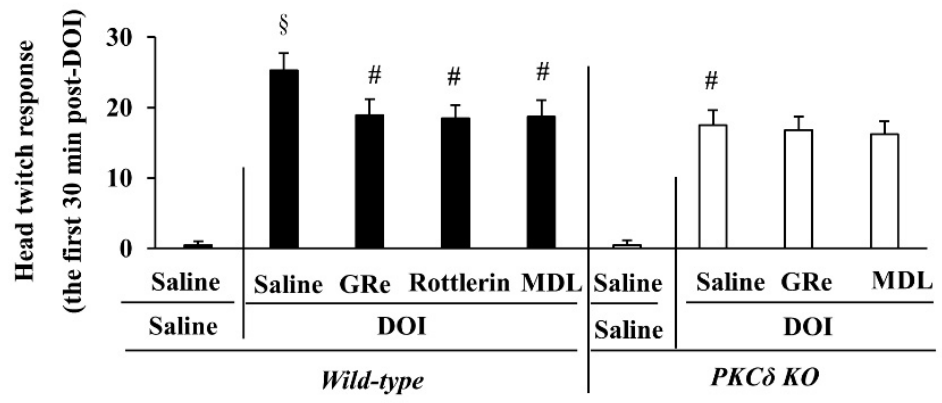

Figure 7. Cont. 
E.

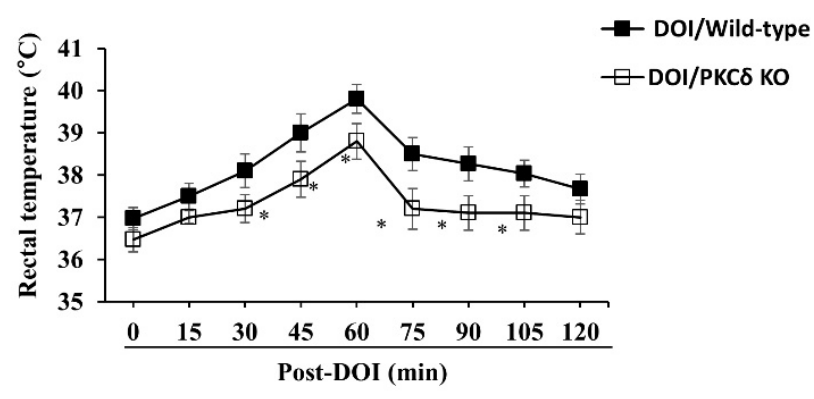

F.

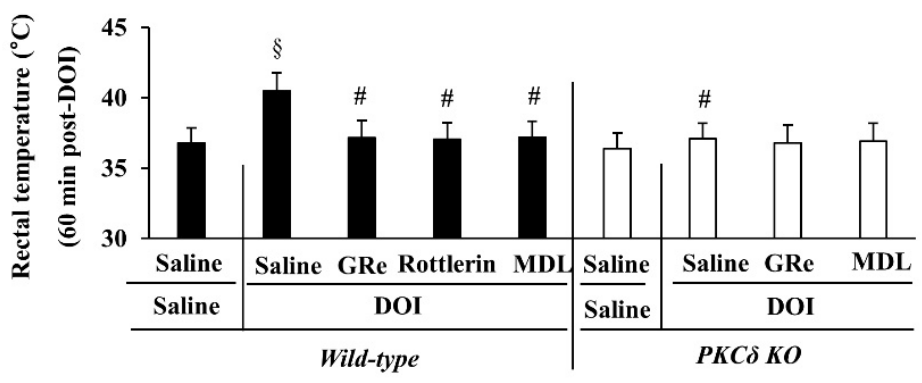

Figure 7. Effect of GRe or MDL on DOI-induced overall serotonergic behavioral score, head twitch response, and changes in rectal temperature in wild-type and $\mathrm{PKC} \delta \mathrm{KO}$ mice. Time course of changes in overall serotonergic behavioral score (A). Effect of GRe or MDL on DOI-induced serotonergic behavior within the first $30 \mathrm{~min}$ (B). Time course of changes in head twitch response (C). Effect of GRe or MDL on DOI-induced head twitch response within the first $30 \mathrm{~min}$ (D). Time course of changes in rectal temperature (E). Effect of GRe or MDL on hyperthermia 60 min post-DOI. Data are expressed as the mean \pm SEM (6 animals/group). GRe, ginsenoside Re; MDL, MDL11939; DOI, 2,5-dimethoxy-4-iodo-amphetamine; PKC $\delta$ KO, PKC $\delta$ knockout mice. ${ }^{* *} p<0.01$ vs. saline/saline/wild-type. ${ }^{\S} p<0.01$ vs. saline/saline/wild-type. ${ }^{\#} p<0.05$ vs. DOI/wild-type or saline/DOI/wild-type. Two-way ANOVA (A,C,E) or one-way ANOVA (B,D,F) was performed for statistical analysis followed by Fisher's LSD pairwise comparisons. For more details refer to Supplementary Figure S2.

Because DOI-induced serotonergic behavioral scores and head twitch response were more prominent in the first $30 \mathrm{~min}$ than in the second $30 \mathrm{~min}$ post-treatment, the effects of GRe, rottlerin, or MDL on the alterations in serotonergic behavioral score and head twitch response were evaluated during the first $30 \mathrm{~min}$. In addition, the effect of GRe, rottlerin, or MDL on hyperthermia was examined $60 \mathrm{~min}$ post-DOI administration because hyperthermia was most evident at that time.

As shown in Figure 7B,D,F, GRe, rottlerin, or MDL significantly alleviated the overall serotoninergic behavioral score ( $p<0.05$ vs. saline/DOI), head twitch response ( $p<0.05$ vs. saline/DOI), and hyperthermia ( $p<0.05 \mathrm{vs}$. saline/DOI) induced by DOI in wild-type mice. Consistently, PKC $\delta$ KO significantly mitigated the overall serotonergic behavioral score ( $p<0.05$ vs. saline/DOI/wild-type), head twitch response ( $p<0.05$ vs. saline/DOI/wildtype), and hyperthermia ( $p<0.05$ vs. saline/DOI/wild-type) in mice. The effects of PKC $\delta$ KO were comparable to those of rottlerin. In addition, neither GRe nor MDL had significant additional effects on PKC $\delta$ KO-mediated attenuation of the DOI-induced behavioral toxicity in mice.

\section{Discussion}

It is known that PKC is a critical molecular factor in the regulation of 5-HT receptors $[67,68]$. The 5-HT2 receptor family is related to the phosphorylation of PKC isozymes [69]. Moreover, PKC modulation is required for the internalization of 5- $\mathrm{HT}_{2 \mathrm{~A}}$ 
receptor $[70,71]$. There is evidence that $5-\mathrm{HT}_{1 \mathrm{~A}}$ and $5-\mathrm{HT}_{2 \mathrm{~A}}$ receptors are mainly responsible for developing serotonin syndrome [35,54,55,72]. Other studies also have provided the insight that the $5-\mathrm{HT}_{2 \mathrm{~A}}$ receptor is closely associated with serotonergic behavioral responses $[13,73]$.

We recently demonstrated that PKC $\delta$ might mediate serotonergic syndrome behaviors $[35,54,55]$. We also indicated that the neuroprotective effects mediated by ginsenoside are due to their antioxidant activity, mainly by alleviating synaptosomal/mitochondrial oxidative stress and mitochondrial dysfunction $[10,12,13,42,74]$. Similarly, the observations of the present study show that DOI-induced serotonergic behaviors are elicited mainly by mitochondrial oxidative stress, impaired enzymatic antioxidant system (i.e., reduced mitochondrial activity of GPx), mitochondrial translocation of PKC $\delta$, decreases in mitochondrial transmembrane potential and mitochondrial complex (I > II) activity, and increased level of intra-mitochondrial $\mathrm{Ca}^{2+} ; \mathrm{GRe}$ or $5-\mathrm{HT}_{2 \mathrm{~A}}$ receptor antagonist MDL inhibits these morbid scenarios by inhibiting PKC $\delta$.

Mitochondria are susceptible to oxidant, pro-inflammatory, and pro-apoptotic effects $[75,76]$. It is well-known that mitochondrial disturbances, such as alterations in the mitochondrial transmembrane potential, generate oxidative stress [76,77]. In addition, in vitro study in SH-SY5Y cells revealed that PKC $\delta$ might be responsible for the increased mitochondrial oxidative stress [78]. Moreover, our previous studies suggested that GRe exhibited protective effects against dopaminergic toxicity caused by methamphetamine, an amphetamine analog, via PKC $\delta$-dependent mitochondrial oxidative stress and mitochondrial GPx activity in vitro/in vivo [12,13], indicating that mitochondria might be an intracellular target of GRe.

In this study, DOI treatment caused a constant and significant increase in SOD activity (mitochondria > cytosol) in the hypothalamus of wild-type mice, whereas it did not implicate a simultaneous increase in GPx activity, particularly in the mitochondrial fraction. Increased SOD activity may increase $\mathrm{H}_{2} \mathrm{O}_{2}$ accumulation, facilitate Fenton reaction, and result in irreversible cellular oxidative damage caused by lipid peroxidation (HNE)/protein oxidation/ROS [66]. Our observation of increased oxidative parameters indicates that GPx activity mainly modifies these endpoints rather than SOD. Furthermore, significant elevation of SOD-1 and SOD-2 activity in wild-type mice could be considered by the increased superoxide anion production during the oxidative insult caused by DOI. Thus, it is speculated that PKC $\delta$ inhibition or GRe-mediated GPx induction may be accountable for dropping $\mathrm{H}_{2} \mathrm{O}_{2}$ levels. Interestingly, as PKC $\delta$ is a well-known redox-sensitive kinase [79], oxidative stress has been shown to upregulate PKC $\delta$ activity and facilitate its mitochondrial translocation [43]. Upon mitochondrial translocation, PKC $\delta$ induces mitochondrial dysfunction and concurrent oxidative stress, as mentioned above. Thus, PKC $\delta$ can be an important mediator of positive feedback amplifiers between oxidative stress and mitochondrial dysfunction [43]. Considering our previous reports $[35,54,55]$ and the present results showing that PKC $\delta$ plays a critical role in inducing serotonergic behaviors mediated by $5-\mathrm{HT}_{1 \mathrm{~A}}$ or $5-\mathrm{HT}_{2 \mathrm{~A}}$ receptors, it is suggested that DOI-induced oxidative stress contributes to the induction of serotonergic behaviors, and that GRe-mediated antioxidant potential is important for preventing DOI-induced serotonergic behaviors.

Handy et al. (2009) proposed that mitochondrial functions were regulated by GPx-1 to modulate redox-dependent cellular responses [80]. Moreover, GPx-1 KO increased mitochondrial oxidative stress in association with loss of mitochondrial energy production [81]. It is important to note that the GRe-mediated protective potential with the recovery of mitochondrial function requires inhibition of $\mathrm{PKC} \delta$. It is also plausible that GRe protects against DOI-induced mitochondrial impairment through the induction of GPx activity by inhibiting PKC $\delta$. Hence, preservation of mitochondrial transmembrane potential by GRe or inhibition of PKC $\delta$ may be critical for the restoration of mitochondrial function.

We observed here that DOI, as a 5- $\mathrm{HT}_{2 \mathrm{~A}}$ agonist and an amphetamine analog, facilitated intramitochodrial $\mathrm{Ca}^{2+}$ accumulation, which further potentiated mitochondrial oxidative stress and also impaired mitochondrial transmembrane potential. Increased in- 
tracellular $\mathrm{Ca}^{2+}$ promoted the intramitochondrial $\mathrm{Ca}^{2+}$ accumulation when $\mathrm{Ca}^{2+}$ influx was more than total $\mathrm{Ca}^{2+}$ efflux [82]. This excessive mitochondrial $\mathrm{Ca}^{2+}$ may cause uncoupling of mitochondrial electron transport and eventually lead to oxidative damage. We speculate that GRe might attenuate $\mathrm{Ca}^{2+}$ influx via inhibition of the mitochondrial translocation of $P K C \delta$, reflecting that GRe primarily restores mitochondrial function.

The effect of DOI on hypothalamic serotonin release has not been well understood. However, previous studies have shown that systemic administration of DOI decreases the extracellular serotonin release [83-85], while intra-prefrontal cortical infusion of DOI increases the extracellular serotonin release $[86,87]$ in the prefrontal cortex. Therefore, it remains to be elucidated whether systemic or intrahypothalamic DOI administration significantly affects the serotonin release in the hypothalamus.

$5-\mathrm{HT}_{2 \mathrm{~A}}$ receptor-induced serotonergic burden was particularly specific in the hypothalamus $[55,88,89]$. Consistently, DOI-induced increased expression of c-Fos, a redoxsensitive factor, in the hypothalamus [90], was attenuated by $5-\mathrm{HT}_{2 \mathrm{~A}}$ antagonist (i.e., MDL100907) [90]. Moreover, immunocytochemical and pharmacological data indicates that DOI principally activates $5-\mathrm{HT}_{2 \mathrm{~A}}$ receptors [91], reflecting the importance of modulation of hypothalamic $5-\mathrm{HT}_{2 \mathrm{~A}}$ receptor. We found that serotonergic behaviors triggered by $5-\mathrm{HT}_{1 \mathrm{~A}}$ receptors paralleled those by $5-\mathrm{HT}_{2 \mathrm{~A}}$ receptors $[35,54]$. However, either one played an opposite role in thermoregulation [92]; for example, activation of 5- $\mathrm{HT}_{1 \mathrm{~A}}$ causes hypothermia [35], whereas the stimulation of $5-\mathrm{HT}_{2 \mathrm{~A}}$ receptors activates a hyperthermic response $[29,93]$. This phenomenon remains to be explored further.

Importantly, serotonin syndrome and hyperthermia can be modulated by therapeutic intervention of the 5- $\mathrm{HT}_{2 \mathrm{~A}}$ receptor antagonist, cyproheptadine, and ketanserin [14,29]. In addition, it has been reported that head twitch response is specifically mediated by the $5-\mathrm{HT}_{2 \mathrm{~A}}$ receptor $[94,95]$, and this effect is alleviated by the antagonism of $5-\mathrm{HT}_{2 \mathrm{~A}}$ receptor [36]. Furthermore, in addition to traditional serotonergic behaviors, DOI also induced head twitch response in wild-type mice. Consistently, antagonism of $5-\mathrm{HT}_{2 \mathrm{~A}}$ receptor (i.e., MDL) ameliorated serotonergic impairments, suggesting that $5-\mathrm{HT}_{2 \mathrm{~A}}$ receptors specifically mediate DOI-induced serotonergic impairments. Among different serotonin receptors, $5-\mathrm{HT}_{2 \mathrm{~A}}$ may be associated with complex behaviors [82]. Earlier studies suggested that head twitch response in mice represented a sort of hallucinogenic behavior $[95,96]$, since hallucinogenic agents induce head twitch response in rodents. Thus, DOI is a frequently used pharmacological tool in the head twitch response studies of hallucinogens. Interestingly, mice lacking $5-\mathrm{HT}_{2 \mathrm{~A}}$ receptors do not show a head twitch response to DOI. In contrast, restoration of cortical neuronal $5-\mathrm{HT}_{2 \mathrm{~A}}$ receptors reinstates the DOI potential for inducing head twitch response in the 5- $\mathrm{HT}_{2 \mathrm{~A}}$ receptor $\mathrm{KO}$ mice [97], reflecting the prerequisite role of $5-\mathrm{HT}_{2 \mathrm{~A}}$ receptors in inducing head twitch response.

In the current study, GRe or rottlerin, or MDL itself without DOI, did not induce significant behavioral or thermal changes (Supplementary Figure S3). Although we did not further examine their effect on the mitochondrial and antioxidant/prooxidant parameters in the absence of DOI in the present study, we have previously reported that GRe or rottlerin alone did not significantly affect the mitochondrial function, mitochondrial/cytosolic antioxidant defense system, or oxidative burden in various brain regions, including the striatum [13,41,46], prefrontal cortex [10], and hippocampus [42]. Nevertheless, the possibility that GRe, rottlerin, or MDL per se exerts its own effect on mitochondrial/cytosolic regulation cannot be ruled out, and it remains to be determined.

Our findings indicated that GRe attenuated the DOI-induced serotonergic impairments via the recovery from mitochondrial stress by PKC $\delta$ inhibition (genetic or pharmacological) in mice. Because GRe or MDL did alter PKC $\delta$ KO-mediated protective potentials in mice, it is plausible that $\mathrm{PKC} \delta$ may be a mechanistic target for DOI-elicited $5-\mathrm{HT}_{2 \mathrm{~A}}$ receptor activation.

In conclusion, our results suggest that PKC $\delta$ activation followed by mitochondrial burden might contribute to the serotonergic behaviors induced by DOI, and that the GRe- 
mediated protective potential regulated by PKC $\delta$ inhibition may lead to a novel therapeutic intervention against serotonergic behaviors.

\section{Materials and Methods}

\subsection{Preparation of GRe}

Mountain-cultivated ginseng (MCG; Panax ginseng) was purchased from Pyungchang, Kangwon Province, Republic of Korea, in August 2014. Dried MCG (5 kg) was extracted with $95 \%$ ethyl alcohol for $4 \mathrm{~h}$ at $78{ }^{\circ} \mathrm{C}$, followed by concentration in vacuum. Ethyl alcohol extract $1320 \mathrm{~g}$ was dissolved in $1500 \mathrm{~mL}$ of water and extracted with diethyl ether $(1500 \mathrm{~mL})$. The water fraction was then evaporated. The water fraction $(1214 \mathrm{~g})$ was subjected to column chromatography over Diaion $(5 \mathrm{~kg})$ and eluted sequentially with $\mathrm{H} 2 \mathrm{O}$, $30 \% \mathrm{MeOH}, 50 \% \mathrm{MeOH}, 70 \% \mathrm{MeOH}$, and $100 \% \mathrm{MeOH}$. The $30 \% \mathrm{MeOH}$ fraction (12.5 g) was chromatographed on ODS (C-18) gel (1 kg) with eluting solvents of $50 \% \mathrm{MeOH}$ to give four subfractions (F1-F4). The F3 fraction ( $3.7 \mathrm{~g}$ ) was further subjected to silica gel column chromatography ( $500 \mathrm{~g}$, $\left.\mathrm{CHCl} 3: \mathrm{MeOH}: \mathrm{H}_{2} \mathrm{O}=70: 30: 4 \mathrm{v} / \mathrm{v}\right)$ to produce GRe (650 $\mathrm{mg})$ [98].

\subsection{Animals}

All experiments in this study, including the treatment of animals, were performed according to the National Institutes of Health (NIH) Guide for the Humane Care and Use of Laboratory Animals (NIH Publication No. 85-23, 1985; grants.nih.gov/grants/ olaw / references/PHSPolicyLabAnimals.pdf; August 2019). All experiments were performed under the Institute for Laboratory Research (ILAR) Guidelines for the Care and Use of Laboratory Animals. Mice were caged in a room maintained at $22 \pm 0.5{ }^{\circ} \mathrm{C}$ with 12:12 h light/dark cycle and fed ad libitum. All mice were allowed to adapt to the laboratory conditions for at least 2 weeks before the experiments. A breeding pair of PKC $\delta( \pm)$ mice (C57BL/6J background) was gifted by Dr. K. I. Nakayama (Dept. of Molecular Genetics, Medical Institute of Bioregulation, Kyushu University, Fukuoka, Japan) [99]. These mice were further bred into the C57BL/6J background for six generations. Male C57BL/6J background mice were used as wild-type mice in our experiments. DNA was obtained from the tails of mice for the genotyping of wild-type and PKC $\delta$ $\mathrm{KO}$ mice. Genotyping primers for polymerase chain reaction (PCR) were as follows: $5^{\prime}$-GGAAGAATAAGAAACTGCATCACC-3' and 5'-GAAGGAGCCAGAACCGAAAG$3^{\prime}$ for endogenous detection, and 5'-GGAAGAATAAGAAA CTGCATCACC- $3^{\prime}$ and $5^{\prime}-$ TGGGGTGGGATTAG ATAAATG-3' for mutant detection (Bioneer Corporation, Daejeon, Korea).

\subsection{Drug Treatment}

GRe, DOI (Sigma-Aldrich, St. Louis, MO, USA), and MDL11,939 (MDL; SigmaAldrich), a $5-\mathrm{HT}_{2 \mathrm{~A}}$ receptor antagonist, were dissolved in sterile saline immediately before use. The PKC $\delta$ inhibitor, rottlerin (Biomol Research Laboratories Inc., Plymouth, PA, USA), was dissolved in dimethyl sulfoxide as a stock solution and stored at $-20^{\circ} \mathrm{C}$. Rottlerin was further diluted in sterile saline at a concentration of $1 \mu \mathrm{g} / \mu \mathrm{L}$ immediately before use.

In the first experiment, male $\mathrm{PKC} \delta \mathrm{KO}$ and wild-type mice, weighing approximately $23 \pm 2 \mathrm{~g}$, received a single dose of DOI $(2.5 \mathrm{mg} / \mathrm{kg}$, i.p.) or saline. Temporal behavioral patterns and changes in rectal temperature were evaluated for 1 and $2 \mathrm{~h}$, respectively. The application of DOI was based on previous studies [100,101]. In the second experiment, male PKC $\delta \mathrm{KO}$ and wild-type mice were injected with GRe $(10 \mathrm{mg} / \mathrm{kg}$, i.p.) twice a day for $5 \mathrm{~d}$. A single dose of DOI ( $2.5 \mathrm{mg} / \mathrm{kg}$, i.p.) or saline was administered $2 \mathrm{~h}$ after the final treatment with GRe. Additional mice received MDL ( $3 \mathrm{mg} / \mathrm{kg}$, i.p., $30 \mathrm{~min}$ prior to DOI treatment) or rottlerin ( $3 \mu \mathrm{g}$, i.c.v./brain, 6 and $2 \mathrm{~h}$ before DOI treatment). The application of GRe, rottlerin, and MDL were based on our previous study $[13,35,54]$. Serotonergic behaviors and head twitch response were assessed for $30 \mathrm{~min}$ post-DOI-treatment. Rectal temperature was measured at $60 \mathrm{~min}$ post DOI treatment, and the mice were sacrificed 
immediately. The brains were dissected, and the hypothalamus was collected instantly, frozen using liquid nitrogen, and stored at $-70{ }^{\circ} \mathrm{C}$ until analysis. The experimental design is illustrated in Figure 1.

\subsection{Serotonergic Behaviors}

DOI $(2.5 \mathrm{mg} / \mathrm{kg}$, i.p.) was injected after $15 \mathrm{~min}$ of acclimatization in a black-painted cage $(260 \mathrm{~mm} \times 200 \mathrm{~mm} \times 140 \mathrm{~mm})$. Behaviors linked with rodent serotonin syndrome were recorded in ten (the first experiment) or five (the second experiment) different $1 \mathrm{~min}$ time-periods separated by 6-min intervals, starting $5 \mathrm{~min}$ post-DOI administration. In each assessment period, the following behaviors were recorded: intermittent behaviors, including forepaw treading, head weaving, backward movement, and forepaw treading (scored on a scale of $0-4 ; 0=$ absent, $1=$ present once, $2=$ present several times, $3=$ present frequently, 4 = present continuously); continuous behaviors, including straub tail, hind limb abduction, low body posture, and tremor (scored on a scale of $0-4 ; 0=$ absent, $1=$ perceptible, 2 = weak, 3 = medium, $4=$ maximal). Overall serotonergic behavior scores were calculated for each 1 min time-period, and then summed together $[35,54,102]$.

\subsection{Head Twitch Response}

The number of head twitch responses was measured in ten (the first experiment) or five (the second experiment) different 1 min time-periods separated by 6 min intervals, starting 5 min post-DOI-administration. The number of head twitch responses in each $1 \mathrm{~min}$ period is displayed, or the total number of head twitch response summed from all the periods is shown [36].

\subsection{Rectal Temperature}

Rectal temperature was measured by inserting an oil-lubricated thermometer at least $3 \mathrm{~cm}$ into the mouse rectum under ambient temperature $\left(21 \pm 1^{\circ} \mathrm{C}\right)$. Mice were gently handled to avoid sudden movements. Animals with an unsuccessful attempt of probe insertion were excluded from the group $[35,54]$.

\subsection{Preparation of Cytosolic and Mitochondrial Fraction for Neurochemical and Western Blot Analyses}

Hypothalamic tissues were homogenized using ice-cold homogenization buffer comprising $0.5 \mathrm{mM}$ potassium EGTA, $0.25 \mathrm{M}$ sucrose, $10 \mathrm{mM}$ Tris- $\mathrm{HCl}$ ( $\mathrm{pH}$ 7.4), and protease inhibitor cocktail (Sigma-Aldrich) by using a Dounce homogenizer. Homogenates were centrifuged at $2000 \times \mathrm{g}$ for $10 \mathrm{~min}$, and nuclei and unbroken cells were removed. Further, to obtain crude mitochondrial pellets and cytosolic supernatants, the suspension was centrifuged at 12,000 $\times g$ for $15 \mathrm{~min}$. Crude mitochondrial pellets were suspended in $3 \%$ Ficoll 400 (Sigma-Aldrich) in Ficoll dilution buffer containing $0.1 \mathrm{mM}$ potassium EGTA, $60 \mathrm{mM}$ sucrose, $10 \mathrm{mM}$ Tris- $\mathrm{HCl}$ ( $\mathrm{pH} 7.4$ ), and $0.25 \mathrm{M}$ mannitol. A Ficoll density gradient was formed by pouring crude mitochondrial suspension in 3\% Ficoll over 6\% Ficoll 400 solution. The suspension was centrifuged at $11,500 \times g$ for $10 \mathrm{~min}$ to obtain purified mitochondrial pellets, further resuspended in a buffer containing protease cocktail (pH 7.4), $210 \mathrm{mM}$ mannitol, $5 \mathrm{mM}$ HEPES, and $70 \mathrm{mM}$ sucrose. For Western blot analysis, $100 \mu \mathrm{L}$ lysis buffer was added to mitochondrial pellets [103,104].

\subsection{Mitochondrial Preparation for the Measurement of Mitochondrial Membrane Potential and Intramitochondrial $\mathrm{Ca}^{2+}$ Level}

Sodium pentobarbital $(60 \mathrm{mg} / \mathrm{kg})$ was used to anesthetize the animals and then perfused transcardially with ice-cold homogenization buffer $(30 \mathrm{~mL})$ comprising $20 \mathrm{mM}$ HEPES, $250 \mathrm{mM}$ sucrose, and $1 \mathrm{mM}$ EDTA, pH 7.2.

The animals were then decapitated, following which the hypothalami $(\sim 1 \mathrm{~g})$ were dissected out, rinsed in homogenization buffer $(9 \mathrm{~mL})$, and processed in a tissue homogenizer. The homogenate was centrifuged at $1300 \times g$ for $10 \mathrm{~min}$, supernatant was removed, 
and it was centrifuged again at $10,000 \times g$ for $10 \mathrm{~min}$. Using a hand-held homogenizer, the pellet was then gently resuspended (four strokes) in $30 \mathrm{~mL}$ homogenization buffer and centrifuged at $10,000 \times g$ for $10 \mathrm{~min}$, and the resulting pellet was resuspended and rinsed in an homogenization buffer (EDTA-free). All the centrifugation steps were carried out at $4{ }^{\circ} \mathrm{C}$. The mitochondrial pellet was then resuspended at a final concentration of $\sim 20 \mathrm{mg} / \mathrm{mL}$ in $250 \mathrm{mM}$ sucrose, and placed on ice. This process was completed within an hour $[13,104,105]$.

\subsection{Western Blot Analysis}

Sodium dodecyl sulfate-polyacrylamide gel electrophoresis (SDS-PAGE) $8 \%$ or $10 \%$ was used to separate proteins $(20 \mu \mathrm{g} /$ lane $)$ and followed by transfer onto polyvinylidene difluoride membranes. Then, blocking of membranes was commenced using 5\% non-fat milk for $30 \mathrm{~min}$, followed by overnight incubation with primary antibodies against PKC $\delta$ (1:10,000; Santa Cruz Biotechnology, Santa Cruz, CA, USA), p-PKC $\delta$ at Tyr 311 (1:500; Santa Cruz Biotechnology), COX IV (1:500, Cell Signaling, Danvers, MA, USA), or $\beta$ tubulin (1:50,000, Sigma-Aldrich) at $4{ }^{\circ} \mathrm{C}$. They were then incubated with HRP-conjugated secondary anti-rabbit IgG (1:1000, GE Healthcare, Piscataway, NJ, USA) or anti-mouse $\operatorname{IgG}\left(1: 1000\right.$, Sigma-Aldrich) for 2 h. Enhanced chemiluminescence system (ECL Plus ${ }^{\circledR}, \mathrm{GE}$ Healthcare, Arlington Heights, IL, USA.) was used to visualize membrane, and relative intensities of the bands were measured using PhotoCapt MW (version 10.01 for Windows; Vilber Lourmat, Marne la Vallée, France). Then, all the Western blots were normalized to the intensity of COX IV (mitochondrial fraction) or $\beta$-tubulin (cytosolic fraction) [13,104].

\subsection{Measurement of Mitochondrial Transmembrane Potential}

5,5',6,6'-tetrachloro-1,1',3,3'-tetraethylbenzimidazolycarbocyanine iodide dye (JC-1; Molecular Probes, Eugene, OR, USA) was used to assess mitochondrial transmembrane potential. This dye exists as a green-fluorescent monomer at low membrane potential but reversibly forms red-fluorescent "J-aggregates" at polarized mitochondrial potentials. Briefly, $250 \mu \mathrm{g}$ aliquots of isolated mitochondrial protein from hypothalamic tissues were suspended in respiration buffer comprising $20 \mathrm{mM}$ HEPES, $2.5 \mathrm{mM}$ inorganic phosphates (pH 7.2), $250 \mathrm{mM}$ sucrose, $2 \mathrm{mM} \mathrm{MgCl}_{2}$, and $10 \mathrm{mM}$ succinate $(5 \mathrm{mM}$ glutamate and $2.5 \mathrm{mM}$ maleate gave similar results in all paradigms) in a final volume of $200 \mu \mathrm{L}$. The energized mitochondria were then incubated with $10 \mu \mathrm{M} \mathrm{JC}-1$ for $30 \mathrm{~min}$ at $37{ }^{\circ} \mathrm{C}$, and fluorescence was measured using a fluorescence plate reader (Molecular Devices Inc., Sunnyvale, CA, USA). Mitochondrial polarization was measured by taking the emission ratio from $590 \mathrm{~nm}$ to $535 \mathrm{~nm}$ with excitation at $490 \mathrm{~nm}$ [13,105-108].

\subsection{Measurement of Intramitochondrial $\mathrm{Ca}^{2+}$ Levels}

Mitochondrial fractions $(250 \mu \mathrm{g})$ were incubated at $37{ }^{\circ} \mathrm{C}$ with Rhod-2-AM $(5 \mu \mathrm{M}$; Molecular Probes) for $1 \mathrm{~h}$, followed by washing with $\mathrm{Ca}^{2+}$-free Locke's solution (3-4 times). This reduced form of Rhod-2-AM is a colorless, non-fluorescent dye with a net positive charge, which promotes sequestration into the mitochondria, whereas dye oxidized in the mitochondria and cleaved AM ester are trapped inside the mitochondria. Fluorescence plate reader (Molecular Devices Inc.) was used to measure fluorescence with an excitation wavelength of $549 \mathrm{~nm}$ and emission wavelengths of $581 \mathrm{~nm}$ [13,108-110].

\subsection{Measurement of Complex I Activity}

Isolated mitochondrial samples were added to a reaction mixture comprising $3.5 \mathrm{mg} / \mathrm{mL}$ bovine serum albumin, $25 \mathrm{mM}$ potassium phosphate buffer ( $\mathrm{pH} 7.8), 1 \mu \mathrm{M}$ antimycin $\mathrm{A}$, $70 \mu \mathrm{M}$ decylubiquinone, and $60 \mu \mathrm{M}$ 2,6-dichloroindophenol, and the reaction mixture was incubated at $37^{\circ} \mathrm{C}$ for $3 \mathrm{~min}$. NADH $(0.2 \mathrm{mM})$ was added, and absorbance was measured at $600 \mathrm{~nm}$ for $4 \mathrm{~min}$ at intervals of $60 \mathrm{~s}$ using a microplate reader (Spectra Max Plus 384, Molecular Devices Inc., Sunnyvale, CA, USA). Rotenone $(1 \mu \mathrm{M})$ was then added, and the absorbance was measured again at $600 \mathrm{~nm}$ for $4 \mathrm{~min}$ at intervals of $60 \mathrm{~s}$. One unit of complex 
I activity is defined as $1 \mu \mathrm{moL}$ 2,6-dichloroindophenol reduced per minute, and it was calculated based on the extinction coefficient for 2,6-dichloroindophenol $\left(19.1 \mathrm{mM}^{-1} \mathrm{~cm}^{-1}\right)$. The results have been expressed as a percentage of the control group $[10,108,111]$.

\subsection{Measurement of Mitochondrial Complex II Activity}

Reaction mixtures contained $2 \mathrm{mM}$ EDTA, $80 \mathrm{mM}$ potassium phosphate buffer ( $\mathrm{pH} 7.8$ ), $80 \mu \mathrm{M}$ 2,6-dichloroindophenol, $1 \mathrm{mg} / \mathrm{mL}$ bovine serum albumin, $50 \mu \mathrm{M}$ decylubiquinone, $3 \mu \mathrm{M}$ rotenone, and $1 \mu \mathrm{M}$ antimycin A. These were incubated for $10 \mathrm{~min}$ at $37^{\circ} \mathrm{C}$. Potassium cyanide $(\mathrm{KCN})(0.3 \mathrm{mM})$ and succinate $(10 \mathrm{mM})$ were added to start the reaction. Absorbance at $600 \mathrm{~nm}$ was recorded at $37^{\circ} \mathrm{C}$ for $5 \mathrm{~min}$ at intervals of $1 \mathrm{~min}$, using a microplate reader (Spectra Max Plus 384, Molecular Devices Inc., Sunnyvale, CA, USA). One unit of complex II activity is defined as the reduction of $1 \mu \mathrm{mol}$ 2,6-dichloroindophenol per minute. Calculation of activity was based on the extinction coefficient of 2,6-dichloroindophenol $\left(19.1 \mathrm{mM}^{-1} \mathrm{~cm}^{-1}\right)[10,108,111]$.

\subsection{Determination of ROS}

Cytosolic and mitochondrial fractions were incubated with $5 \mu \mathrm{M} 2^{\prime}, 7^{\prime}$-dichlorofluorescein diacetate (DCFH-DA, Molecular Probes) for $15 \mathrm{~min}$ at $37^{\circ} \mathrm{C}$. The fluorescence intensity was measured at an excitation and emission wavelength of $488 \mathrm{~nm}$ and $528 \mathrm{~nm}$, respectively, using a fluorescence microplate reader (Molecular Devices Inc.) [104,112].

\subsection{Determination of HNE}

OxiSelectTM HNE adduct ELISA kit (Cell Biolabs, Inc., San Diego, CA, USA) was used to determine the quantity of lipid peroxidation by assessing the level of 4-hydroxynonenal (HNE), according to the manufacturer's instruction. Cytosolic and mitochondrial fractions $(100 \mu \mathrm{L})$ at a protein concentration of $10 \mu \mathrm{g} / \mathrm{mL}$ were incubated in a 96-well protein binding plate at $4{ }^{\circ} \mathrm{C}$ overnight. HNE adducts in each well were labeled with HNE antibody after the protein adsorption, followed by HRP-conjugated secondary antibody. Substrate solution was then added to perform colorimetric development. Absorbance was recorded at $450 \mathrm{~nm}$ using a microplate reader (Molecular Devices Inc.), and the standard curve of HNE-BSA was used to calculate the amount of HNE adduct in each sample.

\subsection{Determination of Protein Carbonyl}

Protein oxidation was determined by analyzing the content of protein carbonyl groups using a 2,4-dinitrophenylhydrazine (DNPH)-labeling procedure [113]. DNPH-labeled protein was detected using a microplate reader $[10,13,104,108]$, and the results were represented as nmol of DNPH incorporated/mg protein based on the extinction coefficient for aliphatic hydrazones $\left(21 \mathrm{mM}^{-1} \mathrm{~cm}^{-1}\right)$. BCA Protein Assay kit (Thermo Scientific) was used to measure protein concentration.

\subsection{Determination of $S O D$}

The reaction mixture containing $30 \mu \mathrm{M}$ cytochrome c, $70 \mathrm{mM}$ potassium phosphate buffer ( $\mathrm{pH}$ 7.8), $150 \mu \mathrm{M}$ xanthine, and cytosolic or mitochondrial preparations in phosphate buffer was diluted 10-fold with PBS to a final volume of $3 \mathrm{~mL}$. The reaction was initiated by adding 50 units xanthine oxidase $(10 \mu \mathrm{L})$, and absorbance was measured at $550 \mathrm{~nm}$ by microplate reader (Molecular Devices Inc.). One unit of SOD is defined as the quantity required to inhibit the rate of cytochrome $\mathrm{c}$ reduction by $50 \%$. Total SOD was measured by adding $\mathrm{KCN}(10 \mu \mathrm{M})$ to the medium to inhibit cytochrome oxidase activity. To estimate mitochondrial $\mathrm{Mn}$-SOD activity, $\mathrm{Cu}, \mathrm{Zn}$-SOD activity was abolished by adding $\mathrm{KCN}$ $(1 \mathrm{mM})$ to the mixture. $\mathrm{Cu}, \mathrm{Zn}-\mathrm{SOD}$ activity was calculated by deducting the Mn-SOD activity from the total SOD activity $[10,13]$. 


\subsection{Determination of GPx}

The incubation mixtures contained $0.2 \mathrm{mM} \mathrm{NADPH}, 2 \mathrm{mM}$ reduced glutathione, and 1.4 IU glutathione reductase in $0.05 \mathrm{M}$ potassium phosphate buffer, $\mathrm{pH}$ 7.0. Reactions were initiated by simultaneous addition of cytosolic or mitochondrial fractions $(0.3-0.8 \mathrm{mg}$ protein) and $0.25 \mathrm{mM}$ cumene hydroperoxide. Microplate reader (Molecular Devices Inc.) was used to measure absorbance at $340 \mathrm{~nm}$ at room temperature. The reaction rate at $340 \mathrm{~nm}$ was determined using the NADPH extinction coefficient $\left(6.22 \mathrm{mM}^{-1} \mathrm{~cm}^{-1}\right)$, and GPx activity was expressed as nmol NADPH oxidized per minute per milligram protein at $25^{\circ} \mathrm{C}[10,13,114]$.

\subsection{Statistical Analyses}

In the present study, data analysis was accomplished by one-way analysis of variance (ANOVA) with post-hoc Fisher's least significant difference (LSD) pairwise comparison tests using IBM SPSS ver. 24.0 (IBM Corp., Armonk, NY, USA). Temporal changes in serotonergic behaviors, head twitch response, and rectal temperature were analyzed using twoway ANOVA with post-hoc Fisher's LSD pairwise comparison tests, and $p$-values $<0.05$ reflected statistical significance.

Supplementary Materials: The following are available online at https:/ /www.mdpi.com/article/10 $.3390 /$ ijms22137219/s1, Figure S1. Western blot data of Figure 2 in main text. Figure S2. Effect of GRe or $5-\mathrm{HT}_{2 \mathrm{~A}}$ receptor antagonist MDL on the DOI-induced serotonergic behaviors: head weaving (A), forepaw treading (B), hind-limb abduction (C), straub tail (D), tremor (E), and low body posture (F) in wild-type and PKC $\delta$ KO mice. Supplementary Figure S3. Effect of GRe, rottlerin, or MDL alone on overall serotonergic behavioral score (A), head twitch response (B), and rectal temperature (C) in wild-type and PKC $\delta$ KO mice.

Author Contributions: Conceptualization, E.-J.S., J.H.J., S.K.K. and H.-C.K.; methodology, E.-J.S., B.-T.N., N.S., S.K.K. and H.-C.K.; software, N.S., E.-J.S. and Y.H.C.; validation, E.-J.S. and J.H.J.; investigation and visualization, J.K.B., S.-Y.N., Y.H.C. and Y.L.; data curation, B.-T.N., N.S., E.-J.S. and T.N.; writing—original draft preparation, H.-C.K.; writing—review and editing, E.-J.S. and H.-C.K.; supervision, E.-J.S., J.H.J., S.K.K., T.N. and H.-C.K.; funding acquisition, H.-C.K. and Y.L.; formal analysis, H.-C.K. and S.K.K. All authors have read and agreed to the published version of the manuscript.

Funding: This study was performed with the support of the R\&D Program for Forest Science Technology (Project No. 2020203C10-2122-BA01) provided by Korea Forest Service (Korea Forestry Promotion Institute), and with the support of research grant \#19182MFDS410 from Korea Food and Drug Administration, Republic of Korea.

Institutional Review Board Statement: All experiments in this study involving animals' treatment were performed in strict accordance with the National Institutes of Health (NIH) Guide for the Humane Care and Use of Laboratory Animals (NIH Publication No.85-23, 1985; grants.nih.gov/grants/ olaw/references/PHSPolicyLabAnimals.pdfwww.dels.nas.edu/ila; August 2019). The present study was carried out according to the Institute for Laboratory Research (ILAR) Guidelines for the Care and Use of Laboratory Animals.

Informed Consent Statement: Not applicable.

Data Availability Statement: The data used and/or analyzed during the current study are available from the corresponding author on reasonable request.

Conflicts of Interest: The authors declare that they have no conflict interests.

\section{References}

1. Lü, J.M.; Yao, Q.; Chen, C. Ginseng compounds: An update on their molecular mechanisms and medical applications. Curr. Vasc. Pharmacol. 2009, 7, 293-302. [CrossRef] [PubMed]

2. Christensen, L.P. Ginsenosides chemistry, biosynthesis, analysis, and potential health effects. Adv. Food Nutr. Res. 2009, 55, 1-99. [CrossRef]

3. Attele, A.S.; Wu, J.A.; Yuan, C.S. Ginseng pharmacology: Multiple constituents and multiple actions. Biochem. Pharmacol. 1999, 58, 1685-1693. [CrossRef] 
4. Ko, S.K.; Bae, H.M.; Cho, O.S.; Im, B.O.; Chung, S.H.; Lee, B.Y. Analysis of ginsenoside composition of ginseng berry and seed. Food Sci. Biotechnol. 2008, 17, 1379-1382.

5. Ko, S.K.; Cho, O.S.; Bae, H.M.; Im, B.O.; Lee, O.H.; Lee, B.Y. Quantitative analysis of ginsenosides composition in flower buds of various ginseng plants. J. Korean Soc. Appl. Biol. Chem. 2011, 54, 154-157. [CrossRef]

6. Joo, K.M.; Lee, J.H.; Jeon, H.Y.; Park, C.W.; Hong, D.K.; Jeong, H.J.; Lee, S.J.; Lee, S.Y.; Lim, K.M. Pharmacokinetic study of ginsenoside Re with pure ginsenoside Re and ginseng berry extracts in mouse using ultra performance liquid chromatography/mass spectrometric method. J. Pharm. Biomed. Anal. 2010, 51, 278-283. [CrossRef] [PubMed]

7. Xie, J.T.; Shao, Z.H.; Vanden Hoek, T.L.; Chang, W.T.; Li, J.; Mehendale, S.; Wang, C.Z.; Hsu, C.W.; Becker, L.B.; Yin, J.J.; et al. Antioxidant effects of ginsenoside Re in cardiomyocytes. Eur. J. Pharmacol. 2006, 532, 201-207. [CrossRef] [PubMed]

8. Kim, Y.K.; Yoo, D.S.; Xu, H.; Park, N.I.; Kim, H.H.; Choi, J.E.; Park, S.U. Ginsenoside content of berries and roots of three typical Korean ginseng (Panax ginseng) cultivars. Nat. Prod. Commun. 2009, 4, 903-906. [CrossRef]

9. Dang, D.K.; Shin, E.J.; Kim, D.J.; Tran, H.Q.; Jeong, J.H.; Jang, C.G.; Nah, S.Y.; Jeong, J.H.; Byun, J.K.; Ko, S.K.; et al. Ginsenoside Re protects methamphetamine-induced dopaminergic neurotoxicity in mice via upregulation of dynorphin-mediated $\mathrm{k}$-opioid receptor and downregulation of substance P-mediated neurokinin1 receptor. J. Neuroinflammation 2018, 15, 52. [CrossRef]

10. Tran, T.V.; Shin, E.J.; Dang, D.K.; Ko, S.K.; Jeong, J.H.; Nah, S.Y.; Jang, C.G.; Lee, Y.J.; Toriumi, K.; Nabeshima, T.; et al. Ginsenoside Re protects against phencyclidine-induced behavioral changes and mitochondrial dysfunction via interactive modulation of glutathione peroxidase-1 and NADPH oxidase in the dorsolateral cortex of mice. Food Chem. Toxicol. 2017, 110, 300-315. [CrossRef]

11. Tu, T.T.; Sharma, N.; Shin, E.J.; Tran, H.Q.; Lee, Y.J.; Jeong, J.H.; Jeong, J.H.; Nah, S.Y.; Tran, H.P.; Byun, J.K.; et al. Ginsenoside Re Protects Trimethyltin-Induced Neurotoxicity via Activation of IL-6-Mediated Phosphoinositol 3-Kinase/Akt Signaling in Mice. Neurochem. Res. 2017, 42, 3125-3139. [CrossRef] [PubMed]

12. Nam, Y.; Wie, M.B.; Shin, E.J.; Nguyen, T.T.; Nah, S.Y.; Ko, S.K.; Jeong, J.H.; Jang, C.G.; Kim, H.C. Ginsenoside Re protects methamphetamine-induced mitochondrial burdens and proapoptosis via genetic inhibition of protein kinase $C$ delta in human neuroblastoma dopaminergic SH-SY5Y cell lines. J. Appl. Toxicol. 2015, 35, 927-944. [CrossRef] [PubMed]

13. Shin, E.J.; Shin, S.W.; Nguyen, T.T.; Park, D.H.; Wie, M.B.; Jang, C.G.; Nah, S.Y.; Yang, B.W.; Ko, S.K.; Nabeshima, T.; et al. Ginsenoside Re rescues methamphetamine-induced oxidative damage, mitochondrial dysfunction, microglial activation, and dopaminergic degeneration by inhibiting the protein kinase C $\delta$ gene. Mol. Neurobiol. 2014, 49, 1400-1421. [CrossRef] [PubMed]

14. Boyer, E.W.; Shannon, M. The serotonin syndrome. N. Engl. J. Med. 2005, 352, 1112-1120. [CrossRef]

15. Birmes, P.; Coppin, D.; Schmitt, L.; Lauque, D. Serotonin syndrome: A brief review. CMAJ 2003, 168, 1439-1442.

16. Ener, R.A.; Meglathery, S.B.; Van Decker, W.A.; Gallagher, R.M. Serotonin syndrome and other serotonergic disorders. Pain Med. 2003, 4, 63-74. [CrossRef] [PubMed]

17. Voizeux, P.; Lewandowski, R.; Daily, T.; Ellouze, O.; Bouchot, O.; Bouhemad, B.; Guinot, P.G. Case of Cardiac Arrest Treated with Extra-Corporeal Life Support after MDMA Intoxication. Case Rep. Crit. Care 2019, 2019, 7825915. [CrossRef] [PubMed]

18. Nadkarni, G.N.; Hoskote, S.S.; Piotrkowski, J.; Annapureddy, N. Serotonin syndrome, disseminated intravascular coagulation, and hepatitis after a single ingestion of MDMA in an Asian woman. Am. J. Ther. 2014, 21, e117-e119. [CrossRef] [PubMed]

19. Davies, O.; Batajoo-Shrestha, B.; Sosa-Popoteur, J.; Olibrice, M. Full recovery after severe serotonin syndrome, severe rhabdomyolysis, multi-organ failure and disseminated intravascular coagulopathy from MDMA. Heart Lung. 2014, 43, 117-119. [CrossRef] [PubMed]

20. Dobry, Y.; Rice, T.; Sher, L. Ecstasy use and serotonin syndrome: A neglected danger to adolescents and young adults prescribed selective serotonin reuptake inhibitors. Int. J. Adolesc. Med. Health 2013, 25, 193-199. [CrossRef]

21. Vuori, E.; Henry, J.A.; Ojanperä, I.; Nieminen, R.; Savolainen, T.; Wahlsten, P.; Jäntti, M. Death following ingestion of MDMA (ecstasy) and moclobemide. Addiction 2003, 98, 365-368. [CrossRef] [PubMed]

22. Parrott, A.C. Recreational Ecstasy/MDMA, the serotonin syndrome, and serotonergic neurotoxicity. Pharmacol. Biochem. Behav. 2002, 71, 837-844. [CrossRef]

23. Brush, D.E.; Bird, S.B.; Boyer, E.W. Monoamine oxidase inhibitor poisoning resulting from Internet misinformation on illicit substances. J. Toxicol. Clin. Toxicol. 2004, 42, 191-195. [CrossRef] [PubMed]

24. Suzuki, K. Three cases of acute serotonin syndrome due to psilocybin mushroom poisoning. Chudoku Kenkyu 2016, 29, 33-35. [PubMed]

25. Kinoshita, H.; Ohkubo, T.; Yasuda, M.; Yakushiji, F. Serotonin syndrome induced by dextromethorphan (Medicon) administrated at the conventional dose. Geriatr. Gerontol. Int. 2011, 11, 121-122. [CrossRef]

26. Schwartz, A.R.; Pizon, A.F.; Brooks, D.E. Dextromethorphan-induced serotonin syndrome. Clin. Toxicol. 2008, 46, 771-773. [CrossRef]

27. Ganetsky, M.; Babu, K.M.; Boyer, E.W. Serotonin syndrome in dextromethorphan ingestion responsive to propofol therapy. Pediatr. Emerg. Care 2007, 23, 829-831. [CrossRef] [PubMed]

28. Navarro, A.; Perry, C.; Bobo, W.V. A case of serotonin syndrome precipitated by abuse of the anticough remedy dextromethorphan in a bipolar patient treated with fluoxetine and lithium. Gen. Hosp. Psychiatry 2006, 28, 78-80. [CrossRef]

29. Isbister, G.K.; Buckley, N.A. The pathophysiology of serotonin toxicity in animals and humans: Implications for diagnosis and treatment. Clin. Neuropharmacol. 2005, 28, 205-214. [CrossRef]

30. Souza, M.E.; Polizello, A.C.; Uyemura, S.A.; Castro-Silva, O.; Curti, C. Effect of fluoxetine on rat liver mitochondria. Biochem. Pharmacol. 1994, 48, 535-541. [CrossRef] 
31. Nahon, E.; Israelson, A.; Abu-Hamad, S.; Varda, S.B. Fluoxetine (Prozac) interaction with the mitochondrial voltage-dependent anion channel and protection against apoptotic cell death. FEBS Lett. 2005, 579, 5105-5110. [CrossRef] [PubMed]

32. Curti, C.; Mingatto, F.E.; Polizello, A.C.; Galastri, L.O.; Uyemura, S.A.; Santos, A.C. Fluoxetine interacts with the lipid bilayer of the inner membrane in isolated rat brain mitochondria, inhibiting electron transport and F1F0-ATPase activity. Mol. Cell. Biochem. 1999, 199, 103-109. [CrossRef]

33. Abdel-Razaq, W.; Kendall, D.A.; Bates, T.E. The effects of antidepressants on mitochondrial function in a model cell system and isolated mitochondria. Neurochem. Res. 2011, 36, 327-338. [CrossRef] [PubMed]

34. Scotton, W.J.; Hill, L.J.; Williams, A.C.; Barnes, N.M. Serotonin Syndrome: Pathophysiology, Clinical Features, Management, and Potential Future Directions. Int. J. Tryptophan Res. 2019, 12, 1178646919873925. [CrossRef]

35. Tran, H.Q.; Shin, E.J.; Hoai Nguyen, B.C.; Phan, D.H.; Kang, M.J.; Jang, C.G.; Jeong, J.H.; Nah, S.Y.; Mouri, A.; Saito, K.; et al. $5-\mathrm{HT}_{1 \mathrm{~A}}$ receptor agonist 8-OH-DPAT induces serotonergic behaviors in mice via interaction between PKC $\delta$ and $\mathrm{p} 47 \mathrm{phox}$. Food Chem. Toxicol. 2019, 123, 125-141. [CrossRef]

36. Fox, M.A.; French, H.T.; LaPorte, J.L.; Blackler, A.R.; Murphy, D.L. The serotonin 5-HT(2A) receptor agonist TCB-2: A behavioral and neurophysiological analysis. Psychopharmacology 2010, 212, 13-23. [CrossRef]

37. Haberzettl, R.; Fink, H.; Bert, B. Role of 5-HT(1A)- and 5-HT(2A) receptors for the murine model of the serotonin syndrome. J. Pharmacol. Toxicol. Methods 2014, 70, 129-133. [CrossRef] [PubMed]

38. Takuwa, N.; Ganz, M.; Takuwa, Y.; Sterzel, R.B.; Rasmussen, H. Studies of the mitogenic effect of serotonin in rat renal mesangial cells. Am. J. Physiol. 1989, 257 Pt 2, F431-F439. [CrossRef]

39. Steinberg, S.F. Distinctive activation mechanisms and functions for protein kinase Cdelta. Biochem. J. 2004, 384 Pt 3, 449-459. [CrossRef]

40. Yoshida, K. PKCdelta signaling: Mechanisms of DNA damage response and apoptosis. Cell Signal. 2007, 19, 892-901. [CrossRef] [PubMed]

41. Shin, E.J.; Duong, C.X.; Nguyen, X.T.; Li, Z.; Bing, G.; Bach, J.H.; Park, D.H.; Nakayama, K.; Ali, S.F.; Kanthasamy, A.G.; et al. Role of oxidative stress in methamphetamine-induced dopaminergic toxicity mediated by protein kinase C $\delta$. Behav. Brain Res. 2012, 232, 98-113. [CrossRef]

42. Shin, E.J.; Nam, Y.; Tu, T.H.; Lim, Y.K.; Wie, M.B.; Kim, D.J.; Jeong, J.H.; Kim, H.C. Protein kinase C $\delta$ mediates trimethyltin-induced neurotoxicity in mice in vivo via inhibition of glutathione defense mechanism. Arch. Toxicol. 2016, 90, 937-953. [CrossRef] [PubMed]

43. Shin, E.J.; Hwang, Y.G.; Sharma, N.; Tran, H.Q.; Dang, D.K.; Jang, C.G.; Jeong, J.H.; Nah, S.Y.; Nabeshima, T.; Kim, H.C. Role of protein kinase C $\delta$ in dopaminergic neurotoxic events. Food Chem. Toxicol. 2018, 121, 254-261. [CrossRef] [PubMed]

44. Shin, E.J.; Jeong, J.H.; Sharma, G.; Sharma, N.; Kim, D.J.; Pham, D.T.; Trinh, Q.D.; Dang, D.K.; Nah, S.Y.; Bing, G.; et al. Protein kinase $\mathrm{C} \delta$ mediates methamphetamine-induced dopaminergic neurotoxicity in mice via activation of microsomal epoxide hydrolase. Food Chem. Toxicol. 2019, 133, 110761. [CrossRef] [PubMed]

45. Shin, E.J.; Dang, D.K.; Hwang, Y.G.; Tran, H.Q.; Sharma, N.; Jeong, J.H.; Jang, C.G.; Nah, S.Y.; Nabeshima, T.; Yoneda, Y.; et al. Significance of protein kinase $\mathrm{C}$ in the neuropsychotoxicity induced by methamphetamine-like psychostimulants. Neurochem. Int. 2019, 124, 162-170. [CrossRef] [PubMed]

46. Dang, D.K.; Shin, E.J.; Kim, D.J.; Tran, H.Q.; Jeong, J.H.; Jang, C.G.; Ottersen, O.P.; Nah, S.Y.; Hong, J.S.; Nabeshima, T.; et al. PKC $\delta$-dependent 447 phox activation mediates methamphetamine-induced dopaminergic neurotoxicity. Free Radic. Biol. Med. 2018, 115, 318-337. [CrossRef]

47. Mai, H.N.; Sharma, N.; Shin, E.J.; Nguyen, B.T.; Nguyen, P.T.; Jeong, J.H.; Cho, E.H.; Lee, Y.J.; Kim, N.H.; Jang, C.G.; et al. Exposure to far-infrared ray attenuates methamphetamine-induced impairment in recognition memory through inhibition of protein kinase $C \delta$ in male mice: Comparison with the antipsychotic clozapine. J. Neurosci. Res. 2018, 96, 1294-1310. [CrossRef]

48. Mai, H.N.; Sharma, N.; Shin, E.J.; Nguyen, B.T.; Nguyen, P.T.; Jeong, J.H.; Jang, C.G.; Cho, E.H.; Nah, S.Y.; Kim, N.H.; et al. Exposure to far-infrared rays attenuates methamphetamine-induced recognition memory impairment via modulation of the muscarinic M1 receptor, Nrf2, and PKC. Neurochem. Int. 2018, 116, 63-76. [CrossRef]

49. Shin, E.J.; Duong, C.X.; Nguyen, X.T.; Bing, G.; Bach, J.H.; Park, D.H.; Nakayama, K.; Ali, S.F.; Kanthasamy, A.G.; Cadet, J.L.; et al. PKC $\delta$ inhibition enhances tyrosine hydroxylase phosphorylation in mice after methamphetamine treatment. Neurochem. Int. 2011, 59, 39-50. [CrossRef]

50. Kramer, H.K.; Poblete, J.C.; Azmitia, E.C. 3,4-Methylenedioxymethamphetamine ('Ecstasy') promotes the translocation of protein kinase C (PKC): Requirement of viable serotonin nerve terminals. Brain Res. 1995, 680, 1-8. [CrossRef]

51. Kramer, H.K.; Poblete, J.C.; Azmitia, E.C. Activation of protein kinase C (PKC) by 3,4-methylenedioxymethamphetamine (MDMA) occurs through the stimulation of serotonin receptors and transporter. Neuropsychopharmacology 1997, 17, 117-129. [CrossRef]

52. Wang, Q.; Bubula, N.; Brown, J.; Wang, Y.; Kondev, V.; Vezina, P. PKC phosphorylates residues in the N-terminal of the DA transporter to regulate amphetamine-induced DA efflux. Neurosci. Lett. 2016, 622, 78-82. [CrossRef]

53. Loweth, J.A.; Svoboda, R.; Austin, J.D.; Guillory, A.M.; Vezina, P. The PKC inhibitor Ro31-8220 blocks acute amphetamine-induced dopamine overflow in the nucleus accumbens. Neurosci. Lett. 2009, 455, 88-92. [CrossRef]

54. Tran, H.Q.; Lee, Y.; Shin, E.J.; Jang, C.G.; Jeong, J.H.; Mouri, A.; Saito, K.; Nabeshima, T.; Kim, H.C. PKC $\delta$ knockout mice are [rotected from dextromethorphan-induced serotonergic behaviors in mice: Involvements of downregulation of 5- $\mathrm{HT}_{1 \mathrm{~A}}$ receptor and upregulation of Nrf2-dependent GSH synthesis. Mol. Neurobiol. 2018, 55, 7802-7821. [CrossRef] 
55. Phan, D.H.; Shin, E.J.; Sharma, N.; Hoang Yen, T.P.; Dang, D.K.; Lee, Y.S.; Lee, Y.J.; Nah, S.Y.; Cheong, J.H.; Jeong, J.H.; et al. $5-\mathrm{HT}_{2 \mathrm{~A}}$ receptor-mediated $\mathrm{PKC} \delta$ phosphorylation is critical for serotonergic impairments induced by p-chloroamphetamine in mice. Food Chem. Toxicol. 2020, 141, 111395. [CrossRef]

56. Capela, J.P.; da Costa Araújo, S.; Costa, V.M.; Ruscher, K.; Fernandes, E.; Bastos Mde, L.; Dirnagl, U.; Meisel, A.; Carvalho, F. The neurotoxicity of hallucinogenic amphetamines in primary cultures of hippocampal neurons. Neurotoxicology 2013, 34, $254-263$. [CrossRef] [PubMed]

57. Shin, E.J.; Jeong, J.H.; Kim, A.Y.; Koh, Y.H.; Nah, S.Y.; Kim, W.K.; Ko, K.H.; Kim, H.J.; Wie, M.B.; Kwon, Y.S.; et al. Protection against kainate neurotoxicity by ginsenosides: Attenuation of convulsive behavior, mitochondrial dysfunction, and oxidative stress. J. Neurosci. Res. 2009, 87, 710-722. [CrossRef] [PubMed]

58. Zhou, X.M.; Cao, Y.L.; Dou, D.Q. Protective effect of ginsenoside-Re against cerebral ischemia/reperfusion damage in rats. Biol. Pharm. Bull. 2006, 29, 2502-2505. [CrossRef]

59. González-Burgos, E.; Fernández-Moriano, C.; Lozano, R.; Iglesias, I.; Gómez- Serranillos, M.P. Ginsenosides Rd and Re cotreatments improve rotenone-induced oxidative stress and mitochondrial impairment in SH-SY5Y neuroblastoma cells. Food Chem. Toxicol. 2017, 109 Pt 1, 38-47. [CrossRef]

60. Liu, M.; Bai, X.; Yu, S.; Zhao, W.; Qiao, J.; Liu, Y.; Zhao, D.; Wang, J.; Wang, S. Ginsenoside Re Inhibits ROS/ASK-1 dependent mitochondrial apoptosis pathway and activation of Nrf2-antioxidant response in Beta-amyloid-challenged SH-SY5Y cells. Molecules 2019, 24, 2687. [CrossRef]

61. Halliwell, B. Reactive oxygen species and central nervous system. J. Neurochem. 1992, 59, 1609-1623. [CrossRef] [PubMed]

62. Lismont, C.; Revenco, I.; Frabsen, M. Peroxisomal hydrogen peroxide metabolism and signaling in health and disease. Int. J. Mol. Sci. 2019, 20, 3673. [CrossRef]

63. Sharma, G.; Shin, E.J.; Sharma, N.; Nah, S.Y.; Mai, H.N.; Nguyen, B.T.; Jeong, J.H.; Lei, X.G.; Kim, H.C. Glutathione peroxidase-1 and neuromodulation: Novel potentials of an old enzyme. Food Chem. Toxicol. 2021, 148, 111945. [CrossRef]

64. Chance, B.; Sies, H.; Boveris, A. Hydroperoxide metabolism in mammalian organs. Physiol. Rev. 1979, 59, 527-605. [CrossRef]

65. Xiong, Y.; Shie, F.S.; Zhang, J.; Lee, C.P.; Ho, Y.S. The protective role of cellular glutathione peroxidase against trauma-induced mitochondrial dysfunction in the mouse brain. J. Stroke Cereb. Dis. 2004, 13, 129-137. [CrossRef] [PubMed]

66. Marí, M.; Morales, A.; Colell, A.; García-Ruiz, C.; Kaplowitz, N.; Fernández-Checa, J.C. Mitochondrial glutathione: Features, regulation and role in disease. Biochim. Biophys. Acta. 2013, 1830, 3317-3328. [CrossRef]

67. Ramamoorthy, S.; Giovanetti, E.; Qian, Y.; Blakely, R.D. Phosphorylation and regulation of antidepressant-sensitive serotonin transporters. J. Biol. Chem. 1998, 273, 2458-2466. [CrossRef] [PubMed]

68. Anji, A.; Sullivan Hanley, N.R.; Kumari, M.; Hensler, J.G. The role of protein kinase C in the regulation of serotonin-2A receptor expression. J. Neurochem. 2001, 77, 589-597. [CrossRef]

69. Mizutani, K.; Sonoda, S.; Wakita, H. Ritanserin, a serotonin-2 receptor antagonist, inhibits functional recovery after cerebral infarction. Neuroreport 2018, 29, 54-58. [CrossRef]

70. Bhattacharyya, S.; Puri, S.; Miledi, R.; Panicker, M.M. Internalization and recycling of 5-HT $2 \mathrm{~A}$ receptors activated by serotonin and protein kinase C-mediated mechanisms. Proc. Natl. Acad. Sci. USA 2002, 99, 14470-14475. [CrossRef]

71. Bhattacharyya, S.; Raote, I.; Bhattacharya, A.; Miledi, R.; Panicker, M.M. Activation, internalization, and recycling of the serotonin 2A receptor by dopamine. Proc. Natl. Acad. Sci. USA 2006, 103, 15248-15253. [CrossRef]

72. Haberzettl, R.; Bert, B.; Fink, H.; Fox, M.A. Animal models of the serotonin syndrome: A systematic review. Behav. Brain Res. 2013, 256, 328-345. [CrossRef] [PubMed]

73. Nisijima, K.; Yoshino, T.; Yui, K.; Katoh, S. Potent serotonin 5- $\mathrm{HT}_{2 \mathrm{~A}}$ receptor antagonists completely prevent the development of hyperthermia in an animal model of the 5-HT syndrome. Brain Res. 2001, 890, 23-31. [CrossRef]

74. Shin, E.J.; Koh, Y.H.; Kim, A.Y.; Nah, S.Y.; Jeong, J.H.; Chae, J.S.; Kim, S.C.; Yen, T.P.; Yoon, H.J.; Kim, W.K.; et al. Ginsenosides attenuate kainic acid-induced synaptosomal oxidative stress via stimulation of adenosine $\mathrm{A}(2 \mathrm{~A})$ receptors in rat hippocampus. Behav. Brain Res. 2009, 197, 239-245. [CrossRef]

75. Wu, C.W.; Ping, Y.H.; Yen, J.C.; Chang, C.Y.; Wang, S.F.; Yeh, C.L.; Chi, C.W.; Lee, H.C. Enhanced oxidative stress and aberrant mitochondrial biogenesis in human neuroblastoma SH-SY5Y cells during methamphetamine induced apoptosis. Toxicol. Appl. Pharmacol. 2007, 220, 243-251. [CrossRef] [PubMed]

76. Beauvais, G.; Atwell, K.; Jayanthi, S.; Ladenheim, B.; Cadet, J.L. Involvement of dopamine receptors in binge methamphetamineinduced activation of endoplasmic reticulum and mitochondrial stress pathways. PLoS ONE 2011, 6, e28946. [CrossRef]

77. Basu, A.; Pal, D. Two faces of protein kinase C $\delta$ : The contrasting roles of PKC $\delta$ in cell survival and cell death. Sci. World J. 2010, 10, 2272-2284. [CrossRef] [PubMed]

78. Lee, C.F.; Chen, Y.C.; Liu, C.Y.; Wei, Y.H. Involvement of protein kinase C delta in the alteration of mitochondrial mass in human cells under oxidative stress. Free Radic. Biol. Med. 2006, 40, 2136-2146. [CrossRef] [PubMed]

79. Kanthasamy, A.G.; Kitazawa, M.; Kanthasamy, A.; Anantharam, V. Role of proteolytic activation of protein kinase Cdelta in oxidative stress-induced apoptosis. Antioxid. Redox Signal. 2003, 5, 609-620. [CrossRef]

80. Handy, D.E.; Lubos, E.; Yang, Y.; Galbraith, J.D.; Kelly, N.; Zhang, Y.Y.; Leopold, J.A.; Loscalzo, J. Glutathione peroxidase1 regulates mitochondrial function to modulate redox-dependent cellular responses. J. Biol. Chem. 2009, $284,11913-11921$. [CrossRef] 
81. Esposito, L.A.; Kokoszka, J.E.; Waymire, K.G.; Cottrell, B.; MacGregor, G.R.; Wallace, D.C. Mitochondrial oxidative stress in mice lacking the glutathione peroxidase-1 gene. Free Radic. Biol. Med. 2000, 28, 754-766. [CrossRef]

82. Nicholls, D.G. Mitochondrial calcium function and dysfunction in the central nervous system. Biochim. Biophys. Acta 2009, 1787, 1416-1424. [CrossRef] [PubMed]

83. Garratt, J.C.; Kidd, E.J.; Wright, I.K.; Marsden, C.A. Inhibition of 5-hydroxytryptamine neuronal activity by the 5-HT agonist, DOI. Eur. J. Pharmacol. 1991, 199, 349-355. [CrossRef]

84. Kidd, E.J.; Garratt, J.C.; Marsden, C.A. Effects of repeated treatment with 1-(2,5-dimethoxy-4-iodophenyl)-2-aminopropane (DOI) on the autoregulatory control of dorsal raphe 5-HT neuronal firing and cortical 5-HT release. Eur. J. Pharmacol. 1991, 200, 131-139. [CrossRef]

85. Martín-Ruiz, R.; Puig, M.V.; Celada, P.; Shapiro, D.A.; Roth, B.L.; Mengod, G.; Artigas, F. Control of serotonergic function in medial prefrontal cortex by serotonin-2A receptors through a glutamate-dependent mechanism. J. Neurosci. 2001, 21, 9856-9866. [CrossRef]

86. Bortolozzi, A.; Díaz-Mataix, L.; Toth, M.; Celada, P.; Artigas, F. In vivo actions of aripiprazole on serotonergic and dopaminergic systems in rodent brain. Psychopharmacology 2007, 191, 745-758. [CrossRef]

87. Bortolozzi, A.; Amargós-Bosch, M.; Adell, A.; Díaz-Mataix, L.; Serrats, J.; Pons, S.; Artigas, F. In vivo modulation of 5hydroxytryptamine release in mouse prefrontal cortex by local 5-HT(2A) receptors: Effect of antipsychotic drugs. Eur. J. Neurosci. 2003, 18, 1235-1246. [CrossRef]

88. Sanders-Bush, E.; Steranka, L.R. Immediate and long-term effects of p-chloroamphetamine on brain amines. Ann. N. Y. Acad. Sci. 1978, 305, 208-221. [CrossRef]

89. Perry, K.W.; Kostrzewa, R.M.; Fuller, R.W. Persistence of long-lasting serotonin depletion by p-chloroamphetamine in rat brain after 6-hydroxydopamine lesioning of dopamine neurons. Biochem. Pharmacol. 1995, 50, 1305-1307. [CrossRef]

90. Van de Kar, L.D.; Javed, A.; Zhang, Y.; Serres, F.; Raap, D.K.; Gray, T.S. 5-HT2A receptors stimulate ACTH, corticosterone, oxytocin, renin, and prolactin release and activate hypothalamic CRF and oxytocin-expressing cells. J. Neurosci. 2001, 21, 3572-3579. [CrossRef]

91. Zhang, Y.; Damjanoska, K.J.; Carrasco, G.A.; Dudas, B.; D’Souza, D.N.; Tetzlaff, J.; Garcia, F.; Hanley, N.R.; Scripathirathan, K.; Petersen, B.R.; et al. Evidence that 5-HT2A receptors in the hypothalamic paraventricular nucleus mediate neuroendocrine responses to (-) DOI. J. Neurosci. 2002, 22, 9635-9642. [CrossRef]

92. Gudelsky, G.A.; Koenig, J.I.; Meltzer, H.Y. Thermoregulatory responses to serotonin (5-HT) receptor stimulation in the rat. Evidence for opposing roles of 5-HT2 and 5-HT1A receptors. Neuropharmacology 1986, 25, 1307-1313. [CrossRef]

93. Mazzola-Pomietto, P.; Aulakh, C.S.; Wozniak, K.M.; Hill, J.L.; Murphy, D.L. Evidence that 1-(2,5-dimethoxy-4-iodophenyl)-2aminopropane (DOI)-induced hyperthermia in rats is mediated by stimulation of 5-HT2A receptors. Psychopharmacology 1995, 117, 193-199. [CrossRef]

94. Hoyer, D.; Hannon, J.P.; Martin, G.R. Molecular, pharmacological and functional diversity of 5-HT receptors. Pharmacol. Biochem. Behav. 2002, 71, 533-554. [CrossRef]

95. Willins, D.L.; Meltzer, H.Y. Direct injection of 5-HT2A receptor agonists into the medial prefrontal cortex produces a head-twitch response in rats. J. Pharmacol. Exp. Ther. 1997, 282, 699-706. [PubMed]

96. González-Maeso, J.; Yuen, T.; Ebersole, B.J.; Wurmbach, E.; Lira, A.; Zhou, M.; Weisstaub, N.; Hen, R.; Gingrich, J.A.; Sealfon, S.C. Transcriptome fingerprints distinguish hallucinogenic and nonhallucinogenic 5-hydroxytryptamine 2A receptor agonist effects in mouse somatosensory cortex. J. Neurosci. 2003, 23, 8836-8843. [CrossRef]

97. González-Maeso, J.; Weisstaub, N.V.; Zhou, M.; Chan, P.; Ivic, L.; Ang, R.; Lira, A.; Bradley-Moore, M.; Ge, Y.; Zhou, Q.; et al. Hallucinogens recruit specific cortical 5-HT(2A) receptor-mediated signaling pathways to affect behavior. Neuron 2007, 53, 439-452. [CrossRef]

98. Tran, T.V.; Shin, E.J.; Ko, S.K.; Nam, Y.; Chung, Y.H.; Jeong, J.H.; Jang, C.G.; Nah, S.Y.; Yamada, K.; Nabeshima, T.; et al. Mountaincultivated ginseng attenuates phencyclidine-induced abnormal behaviors in mice by positive modulation of glutathione in the prefrontal cortex of mice. J. Med. Food 2016, 19, 961-969. [CrossRef]

99. Miyamoto, A.; Nakayama, K.; Imaki, H.; Hirose, S.; Jiang, Y.; Abe, M.; Tsukiyama, T.; Nagahama, H.; Ohno, S.; Hatakeyama, S.; et al. Increased proliferation of B cells and auto-immunity in mice lacking protein kinase Cdelta. Nature 2002, 416, 865-869. [CrossRef]

100. Yamada, J.; Sugimoto, Y.; Ohkura, M.; Inoue, K.; Shinozuka, K.; Kunitomo, M. Role of 5-HT(2) receptor subtypes in depletion of 5-HT induced by p-chloroamphetamine in the mouse frontal cortex. Brain Res. 2001, 911, 141-145. [CrossRef]

101. Sugimoto, Y.; Ohkura, M.; Inoue, K.; Yamada, J. Involvement of serotonergic and dopaminergic mechanisms in hyperthermia induced by a serotonin-releasing drug, p-chloroamphetamine in mice. Eur. J. Pharmacol. 2001, 430, 265-268. [CrossRef]

102. Fox, M.A.; Jensen, C.L.; Gallagher, P.S.; Murphy, D.L. Receptor mediation of exaggerated responses to serotonin-enhancing drugs in serotonin transporter (SERT)-deficient mice. Neuropharmacology 2007, 53, 643-656. [CrossRef] [PubMed]

103. Gogvadze, V.; Orrenius, S.; Zhivotovsky, B. Analysis of mitochondrial dysfunction during cell death. Curr. Protoc. Cell Biol. 2003. [CrossRef] [PubMed]

104. Shin, E.J.; Nam, Y.; Lee, J.W.; Nguyen, P.T.; Yoo, J.E.; Tran, T.V.; Jeong, J.H.; Jang, C.G.; Oh, Y.J.; Youdim, M.B.H.; et al. N-Methyl, N-propynyl-2-phenylethylamine (MPPE), a Selegiline Analog, Attenuates MPTP-induced dopaminergic toxicity with guaranteed 
behavioral safety: Involvement of inhibitions of mitochondrial oxidative burdens and p53 gene-elicited pro-apoptotic change. Mol. Neurobiol. 2016, 53, 6251-6269. [CrossRef] [PubMed]

105. Xiong, Y.; Gu, Q.; Peterson, P.L.; Muizelaar, J.P.; Lee, C.P. Mitochondrial dysfunction and calcium perturbation induced by traumatic brain injury. J. Neurotrauma 1997, 14, 23-34. [CrossRef]

106. Bruce-Keller, A.J.; Geddes, J.W.; Knapp, P.E.; McFall, R.W.; Keller, J.N.; Holtsberg, F.W.; Parthasarathy, S.; Steiner, S.M.; Mattson, M.P. Anti-death properties of TNF against metabolic poisoning: Mitochondrial stabilization by MnSOD. J. Neuroimmunol. 1999, 93, 53-71. [CrossRef]

107. Qu, M.; Zhou, Z.; Xu, S.; Chen, C.; Yu, Z.; Wang, D. Mortalin overexpression attenuates beta-amyloid-induced neurotoxicity in SH-SY5Y cells. Brain Res. 2011, 1368, 336-345. [CrossRef]

108. Tran, H.Q.; Shin, E.J.; Saito, K.; Tran, T.V.; Phan, D.H.; Sharma, N.; Kim, D.W.; Choi, S.Y.; Jeong, J.H.; Jang, C.G.; et al. Indoleamine2,3-dioxygenase-1 is a molecular target for the protective activity of mood stabilizers against mania-like behavior induced by d-amphetamine. Food Chem. Toxicol. 2020, 136, 110986. [CrossRef]

109. Mattson, M.P.; Keller, J.N.; Begley, J.G. Evidence for synaptic apoptosis. Exp. Neurol. 1998, 153, 35-48. [CrossRef]

110. Xu, S.; Pi, H.; Chen, Y.; Zhang, N.; Guo, P.; Lu, Y.; He, M.; Xie, J.; Zhong, M.; Zhang, Y.; et al. Cadmium induced Drp1-dependent mitochondrial fragmentation by disturbing calcium homeostasis in its hepatotoxicity. Cell Death Dis. 2013, 4, e540. [CrossRef]

111. Janssen, A.J.; Trijbels, F.J.; Sengers, R.C.; Smeitink, J.A.; van den Heuvel, L.P.; Wintjes, L.T.; Stoltenborg-Hogenkamp, B.J.; Rodenburg, R.J. Spectrophotometric assay for complex I of the respiratory chain in tissue samples and cultured fibroblasts. Clin. Chem. 2007, 53, 729-734. [CrossRef]

112. Lebel, C.P.; Bondy, S.C. Sensitive and rapid quantitation of oxygen reactive species formation in rat synaptosomes. Neurochem. Int. 1990, 17, 435-440. [CrossRef]

113. Oliver, C.N.; Ahn, B.W.; Moerman, E.J.; Goldstein, S.; Stadtman, E.R. Age-related changes in oxidized proteins. J. Biol. Chem. 1987, 262, 5488-5491. [CrossRef]

114. Lawrence, R.A.; Burk, R.F. Glutathione peroxidase activity in selenium-deficient rat liver. Biochem. Biophys. Res. Commun. 1976, 71, 952-958. [CrossRef] 